\title{
Article \\ Ecological Embeddedness in the Maya Built Environment: Inspiration for Contemporary Cities
}

\author{
Naji Akbar ${ }^{1}$, Ismaila Rimi Abubakar ${ }^{2, * \mathbb{D}}$, Ayesha Agha Shah ${ }^{3}$ and Wafa Al-Madani ${ }^{3}$ \\ 1 Department of Interior Architecture, College of Architecture and Planning, Imam Abdulrahman Bin Faisal \\ University, Dammam 31451, Saudi Arabia; nakbar@iau.edu.sa \\ 2 College of Architecture and Planning, Imam Abdulrahman Bin Faisal University, \\ Dammam 31451, Saudi Arabia \\ 3 Department of Architecture and Interior Design, College of Engineering, University of Bahrain, \\ P.O. Box 32038, Zallaq, Bahrain; aashah@uob.edu.bh (A.A.S.); walmadani@uob.edu.bh (W.A.-M.) \\ * Correspondence: irabubakar@iau.edu.sa
}

Citation: Akbar, N.; Abubakar, I.R.; Shah, A.A.; Al-Madani, W. Ecological Embeddedness in the Maya Built Environment: Inspiration for Contemporary Cities. Land 2021, 10, 1360. https://doi.org/10.3390/ land 10121360

Academic Editors: Elizelle Juanee Cilliers and Sarel Cilliers

Received: 18 November 2021

Accepted: 7 December 2021

Published: 9 December 2021

Publisher's Note: MDPI stays neutral with regard to jurisdictional claims in published maps and institutional affiliations.

Copyright: (c) 2021 by the authors. Licensee MDPI, Basel, Switzerland. This article is an open access article distributed under the terms and conditions of the Creative Commons Attribution (CC BY) license (https:// creativecommons.org/licenses/by/ $4.0 /)$.

\begin{abstract}
Cities nowadays are the most significant source of environmental degradation threatening local and global ecosystems. Interestingly, many ancient settlements present excellent lessons and inspiration for addressing our current urban predicaments, given their environmental stewardship. This research explores how the ecologically embedded settlement patterns, building configurations, urban agriculture and home gardening, and water conservation of the Maya-built environment can offer insights about mitigating contemporary urban sustainability challenges. Mayans' respect for nature not only guaranteed sustainable habitats but also engendered one of the most remarkable civilizations in a region that did not offer generous support for human accommodation. The Mayan world view promoted the idea of one spirit dwelling in all humans and other-than-human entities in an environment, making everything sacred and kin to everything else. The regional climate was kept under control by protecting the vegetation that also provided other ecological benefits. Land use was mixed, and residences were constructed with native and recyclable materials utilizing natural light and ventilation. The Mayan civilization inspires us to manage and protect plants, not cut them down; conserve water, not waste it; listen to the environmental feedback, not reject it; and, most importantly, it begs us to embrace nature as our own mother, not disown it as something dispensable. These principles have significant implications on urban land-use planning and policies today.
\end{abstract}

Keywords: ecological embeddedness; environmental sustainability; cities; home gardens; Maya; settlement pattern; urban agriculture; water conservation

\section{Introduction}

The literature strongly suggests that cities today are the major cause of adverse environmental impacts globally, which negatively affect them and the wider landscapes [1-4]. Cities are expected to account for $68 \%$ of the global population by 2050 , with land consumption outpacing population growth by as much as 50\% [5]. This sprawling development pattern has deleterious impacts on the ecosystem, especially biodiversity. The ecological dis-embeddedness of cities, which has divorced people and their activities from the local and regional environments, is among the causes of environmental degradation [6-10]. This has left many societies without concrete guidance that could be drawn from the context of which they are a part. Many scholars have studied this grave situation regarding modern cities and proposed the idea of a different and a better kind of habitat [11-15]. It is now becoming evident that healthy habitats can only be reformulated through developing respect for nature, which can be accomplished by learning lessons from the ecological embeddedness of ancient settlements [16-18].

To explore the past with an intention to seek inspiration for current and future cities, this paper surveys the Mayan built environment, investigating how the settlement pattern, 
building configurations, urban agriculture and home gardening, and water conservation were ecologically embedded. The paper then discusses some important lessons for contemporary-built environments to help mitigate their environmental sustainability challenges. Can we look at the past to reconceive our present and future cities? While some scholars, such as Campbell [13], argue that it would be less relevant, several others opine that exemplary instances of ecological embeddedness and sustainable practices regarding the built environment can be found in past civilizations for us to think about and possibly adapt for the benefit of the present and future generations $[6,7,19,20]$.

Ecological embeddedness is the concept of identifying with the ecosystem of any given region and adhering to the principles of conservation, respect, and reciprocity implemented for the betterment of all stakeholders [21]. The concept consists of an evolving knowledge that is "transgenerational, transcultural, trans-philosophical, and transdisciplinary", gathered through experimentation with and monitoring of ecosystems [22]; it is much more than just a 'know-how' [17]. This understanding of the intricate relationships between the different components of an environment and their effects over longer periods is vital for taking effective sustainability decisions [23]. Turner et al. [24] enumerate six principles of ecological embeddedness: (a) interconnecting and rotating all entities in an environment; (b) environmental feedback and sustainable resource harvesting and reuse; (c) knowledge accumulation and transfer; (d) respectful and collaborative approaches to human activities; (e) associating oneself as a part of one's ancestral land; and (f) acknowledging spirituality in nature.

Dis-embeddedness, on the other hand, is a short-term gains (mainly economic) over long-term benefits (sustainability) approach, discounting the multiplicity of perspectives, looking at humans and nature as a binary, and ignoring spirituality and the call for meaning behind life [10]. The drive towards limitless material accumulation and the disregard for the environment is informed by the idea that humans and other-than-human stakeholders do not need to co-evolve. This fact is exemplified by the current situation in which cities, which cover less than $2 \%$ of the earth's surface, consume $78 \%$ of the energy generated and produce $60 \%$ of greenhouse gas (GHG) emissions [5]. Buildings alone consume over $40 \%$ of generated energy and contribute nearly one-third of GHG emissions in most countries [3]. Consequently, this situation has led not only to environmental degradation, but also to decontextualization and ecological dis-embeddedness of contemporary cities. The following are among the major environmental sustainability challenges faced by contemporary cities.

Air pollution and GHG emissions from buildings, the transportation sector, and industries are important factors undermining urban sustainability. The release of GHG emissions links directly to poor air quality with attendant health risks [3,5]. Likewise, over-dependence on unsustainable fossil-based energy and technologies contributes to environmental pollution. Burning fossil fuels releases carbon dioxide and other greenhouse gases, contributing to global warming and climate change $[2,14]$. Urban heat islands, formed due to increased energy consumption from buildings, hard structures, and concentrated pavements, threaten the sustainable development of urban communities. Moreover, the lack of blue-green infrastructure leads to higher temperatures and undesired climate change $[25,26]$.

Similarly, sprawling development away from the city center leads to a serious challenge of increased mobility, congestion, environmental pollution, and accidents. In addition, the increasing scale of contemporary cities changes the dynamic of the carbon cycle and earth radiation and leads to high infrastructure demands and capital costs. Habitat fragmentation is another prominent issue of extensive urban development that weakens the ecosystem $[4,15,25]$. Furthermore, unsustainable resource consumption and lifestyles are increasingly exerting pressure on the environment, leading to the loss of prime agricultural land, biodiversity, and water resources $[1,9,27,28]$, and unsustainable solid and liquid waste management practices and rising urbanization levels lead to water and land contamination $[29,30]$. Moreover, urban floods are triggered by ineffective land-use patterns and rainfall management [31,32]. 
Additionally, segregated and mono-functional land uses are sustainability challenges that encourage mobility to other zones for urban activities and discourage street-level socioeconomic interactions due to a lack of diversity in land-use planning and overreliance on cars for mobility [11]. Moreover, inequality and poverty are widespread in contemporary cities. These socioeconomic challenges have arisen due to unemployment and spatial mismatch, because of the detachment of homes from workplaces [13,16]. Lastly, urban development in most cities is devoid of public participation, and cities lack public realm and a sense of community, which results in feelings of alienation from the land and community [31].

A review of similar literature indicates that there is dearth of studies on lessons Mayan settlements can offer to help with addressing these urban sustainability challenges. For example, Akbar et al. [16] investigated how the ecological wisdom of Asian traditional settlements can help foster environmental sustainability by addressing contemporary urban challenges, such as disassociation with the land, overcrowding, over dependence on fossilbased energy and technology, GHG emissions, costly and resources-intensive projects, import of foreign ideas and materials, mono-functional urbanism, one-size-fits-all designs, flooding, and the urban heat island (UHI) effect. Possible solutions to these problems can be found in the ecological embeddedness of the Mayan-built environment. For instance, Ashmore [33] studied physically and spiritually meaningful site-planning concepts and principles among the ancient Maya. Munson and Pinzón [34] researched the way early Mayans constructed environmentally sustainable buildings. Murtha [35] demonstrated how low-urban density fostered sustainability in the Mayan-built environment. While Davis-Salazar [36] studied the Mayan-built environment's drainage and flood control, Dine et al. [37] explored the modern lessons of Mayan agriculture towards food security. So far, the present study is the first to extract the ecological embeddedness of Mayans and their settlements and apply their principles toward fostering environmental sustainability in contemporary cities.

This study can help cities mainstream ecological considerations into land-use planning and policymaking. It can also improve our knowledge of the evolving body of literature about the role of and lessons to be learned from the ecological wisdom of ancient-built environment in addressing urban sustainability challenges facing cities today.

\section{Materials and Methods}

\subsection{Maya Background}

The Maya occupied the region which is currently El Salvador, Belize, Guatemala, Honduras, and the southern part of Mexico [38]. This region lies in the tropics, 23.5 degrees north of the equator within the Meso-American region (Figure 1). The ecological understanding of the Maya is well documented. Their civilization faced many challenges, such as unpredictable drought, excessive rainfall, high humidity, a profusion of pests, a shortage of potable water, the inadequacy of irrigation systems, unfavorable karst land [39-41], and a lack of metals during the Classic era [42]. Despite these daunting challenges, the Maya still effectively utilized opportunities present in their land through close observation of and association with nature [43,44].

Large expanses of land occupied by the Maya comprised southern highlands, central tropical lowlands, and less-vegetated northern areas (Figure 1). These are noted by scholars as centers of influence during the great Mayan eras. The highlands, lowlands, and northern areas correspond to the Pre-Classic (1200 BC-250 AD), Classic (250-950 AD), and PostClassic (950-1500 AD) ages, respectively [45]. A considerable population settled in the Maya region during the Late Pre-Classic Period (400 BC-250 AD), requiring them to adapt to the topographic variation as well as the microclimate. Most of the populations were employed in agriculture. By applying a trial-and-error method over years, people were able to modify the landscape to achieve exceptional agricultural production while enhancing the natural carrying capacity of their land at the same time. 


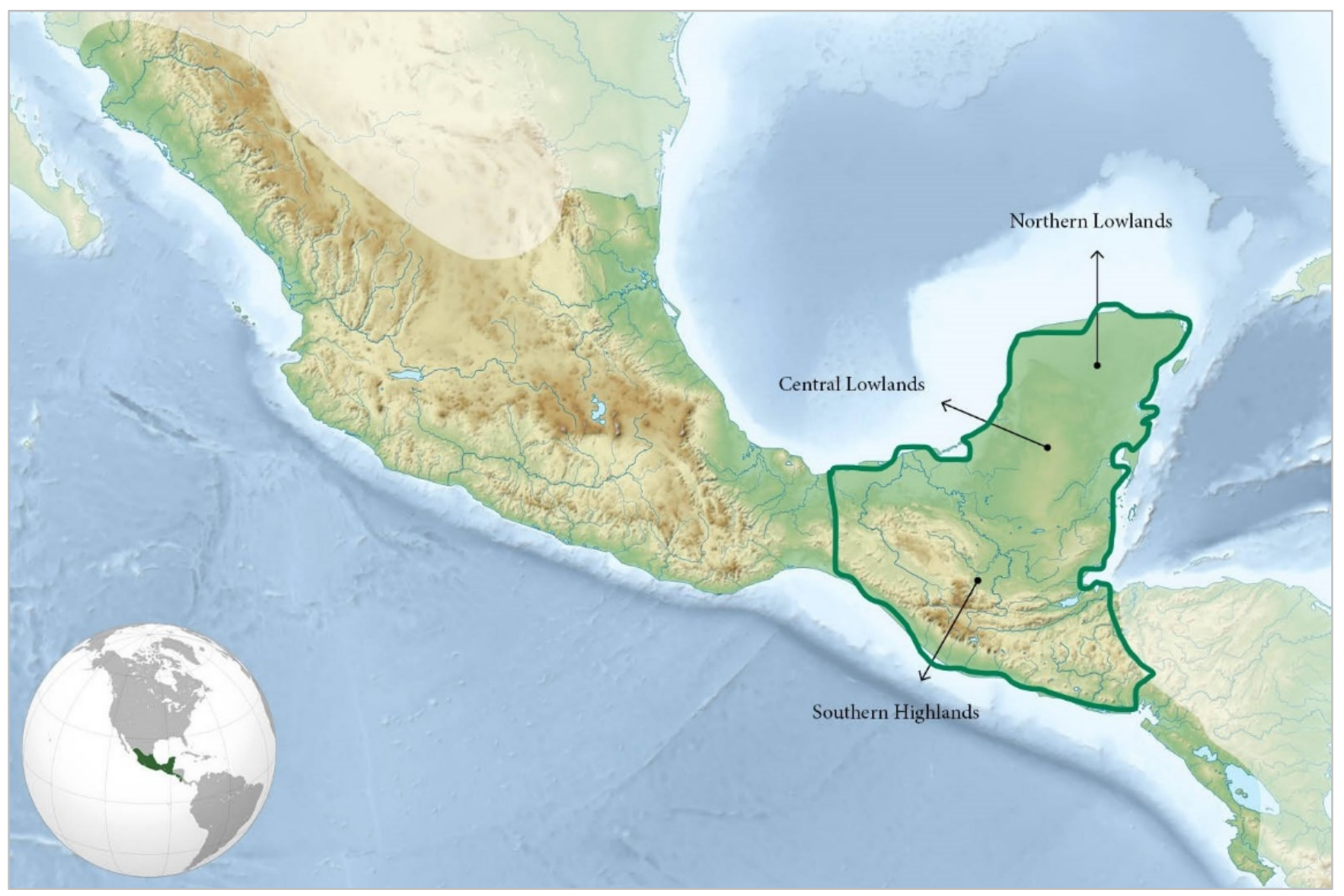

Figure 1. Location of the land occupied by the Maya (inside green boundary) within the Meso-American region [21] [Akbar, 2021].

Time and its passage were significant for the Maya. The movement of heavenly bodies over time indicated when farming and rituals should take place [46]. For this, city elevations and vertical markers in the built environment played a key role. These aligned with certain movements and locations of various stars, which signified important turns in the temporal dimension. The observation of the heavens also designated proper time for crop plantation [47], failure to do so would affect agricultural yield.

The Maya were a society with complex urban systems and activities, as signified by their house mounds, agricultural terraces, raised fields, home gardens, and water reservoirs. Their cities were also places for public gatherings, specialized labor, recreation, and water conservation (especially the lowland locations) for the benefit of urban and rural populations [48]. The kings controlled the water that was available in limited amounts [49]. The urbanites were supported by their rural neighbors, who supplied them with food and various natural resources. Due to this reciprocation, a top-down and bottom-up balance was achieved in decision making regarding resource management and environmental conservation $[50,51]$.

Urbanism has not been thought of as a feature of the Pre-Columbian New World, which is a trend in need of reconsideration. This is attributed to the focus of research on religion, leaving out other factors such as economy, politics, environment, and settlement patterns. While Aztec settlements such as Teotihuacan and Tenochtitlan have been termed urban centers, it is surprising to see that smaller and dispersed Mayan settlements, such as Tikal, Chan Chan, Calakmul, Cahokia, Tiwanaku, and Paquime, are left out as not satisfying the general definition of 'urbanism' according to some scholars. The Mayan-built environment can be considered as urban based on the social and spatial heterogeneity of its settlements, as well as its economic activities, not to mention its complex water conservation systems [52,53]. Furthermore, a multidisciplinary, multivariable, comparative, and cross- 
cultural study may bring out the characteristics of urbanism in Mayan environments and society further [54].

The functionality of the Mayan-built environment conforms to the people's religious thoughts. Even heavenly bodies and their spiritual and physical impacts on earth are part of this conformity. Mayans regarded the earth as a god where plants, animals, land, caves, and mountains were considered sacred and invaluable [55] That is why many Maya settlements were placed around Cenotes (underground water bodies) and caves, providing a meaningful link between people, land, and water. This level of connectedness can provide rich lessons for contemporary settlements threatened by a lack of spirituality and varied sustainability challenges. The following are the main reasons for choosing to study Maya culture: first, Mayan-occupied land appears to be one of the most intriguing historical regions, with ecological wisdom that survives to the present; second, the Mayan-built environment has often been likened to the 'Garden Cities', which remain famous amongst the public, scholars, and planners today; and lastly, significant literature, published over several decades of research and archaeological works, is available to carry out this research.

\subsection{Data Collection and Analysis}

This study employs the desktop research method of reviewing relevant literature to achieve its aim. The method consists of three iterative phases: the problem definition, literature survey, and data analysis [16]. The first phase consisted of identifying and defining the research problem to be investigated. In this study, the focus is on how lessons from the ecological embeddedness of the Mayan-built environment can help to mitigate sustainability challenges facing contemporary cities. The second phase consisted of surveying and gathering relevant literature and secondary data. Using the Web of Science, Scopus, and Google Scholar search engines (globally recognized comprehensive databases), literature related to the study domain were manually selected and downloaded. The identified relevant literature included published articles and books (academic literature) as well as official reports, statistics, urban plans, and maps (grey literature).

Table 1 shows an example of search terms used to identify and download resources using Google Scholar on 10 November 2021. Documents that satisfied the following four inclusion criteria were used. It should be (a) written in the English language; (b) full text; (c) related to the objective of the study; and (d) published after 1990, which was the time when interest in the legacy of Mayan settlements became heightened. After removing duplicates, 86 documents met the criteria and were included in the study.

Table 1. Result of manual search for relevant literature.

\begin{tabular}{ccc}
\hline Search Terms & $\begin{array}{c}\text { No. of Papers } \\
\text { Identified }\end{array}$ & $\begin{array}{c}\text { No. of Papers } \\
\text { Downloaded }\end{array}$ \\
\hline $\begin{array}{c}\text { "Maya built environment" } \\
\text { "Sustainable architecture in Maya" }\end{array}$ & 170 & 32 \\
"Maya water management" & 7 & 5 \\
"Maya ecology" & 324 & 27 \\
"Maya home gardens" & 66 & 24 \\
"Maya + forest" & 66 & 13 \\
"ancient Maya settlement patterns" & 73 & 8 \\
Maya urban form & 245 & 52 \\
"Agriculture + Maya" & 7 & 2 \\
"Maya home gardens" & 89 & 6 \\
"Ancient Maya roads" & 11 & 7 \\
\hline
\end{tabular}

The last phase of the analysis involved organizing the gathered documents based on similarity to the topics set out in Table 1, albeit with some document belonging to more than one group. After this, each document was thoroughly analyzed to extract themes related to the Mayan-built environment that satisfied at least one of the six principles of ecological embeddedness identified earlier [24] or uncovered new ones. The extracted 
themes were finally collated, synthesized, and harmonized, which resulted in four categories: settlement pattern, building configuration, urban agriculture and home gardening, and water conservation. The analysis also involved extracting some quantitative data, such as building floor area and spacing, road width, and the ratio of the built-up areas to green areas from city maps. The quantitative data can help determine the environmental sustainability of settlement patterns. Literature review research has been employed in several studies due to the availability of secondary data online, its low costs, and suitability in exploratory research $[16,29]$.

\section{Results and Discussion}

This section presents and discusses the study findings, divided along the ecological embeddedness of the Mayan-built environment according to the four themes that emerged from data analyses: (1) settlement pattern, (2) building configuration and construction, (3) urban agriculture and home gardening, and (4) water conservation. The paper then discusses some important lessons for contemporary-built environments to help alleviate their environmental sustainability challenges.

\subsection{Settlement Patterns in Maya}

Mayan settlements are famous for their residential clusters, home gardens, ritual and regal centers, and socioeconomic and political activities. Based on this, a city acquired an identity according to its dominant features [56]. It took Maya continuous and intensive procedures of agronomy and landscape treatment to adapt various locations for habitation [44]. As a result, adequate urban characteristics seem to emerge from these habitats such as refined construction, residential clusters [57], home gardens [38,58,59], land-use variation [60], neighborhoods, districts, complex institutions [15,61], market exchanges [62], and developed land and water resource management systems [63]. Often, even small settlements such as Joya de Ceren exhibited the civic and social order found in large settlements [64].

The Mayan world view was manifest in the design and arrangement of their habitat [65]. Their built environment was a patchwork of different and scattered agro-systems. Their land use included terraces, raised fields, kitchen gardens, orchids, slash-and-burn agriculture areas, and natural and created forests. Although land was cleared for urban developments, complete deforestation is not evidenced [43]. As shown in Table 2, only approximately $32 \%$ of central Tikkal was covered by buildings while the remaining $68 \%$ was open spaces and green areas. In contrast, central Chunchucmil is denser with $42 \%$ of the area occupied by buildings. In both settlements, building-floor areas ranged from $300-360 \mathrm{~m}^{2}$ with $0.27-1.38$ dwelling units per hectare, while major roads were $60-70 \mathrm{~m}$ wide and minor roads measured around $20-40 \mathrm{~m}$ wide, which compares well with many contemporary cities.

Table 2. Average road width, development density, and building floor area and spacing in central Tikal and Chunchucmil.

\begin{tabular}{ccccccccc}
\hline Settlement & \multicolumn{3}{c}{ Size (Hectare) } & & \multicolumn{2}{c}{ Buildings } \\
\cline { 2 - 8 } & Developed & $\begin{array}{c}\text { Green and } \\
\text { Open Areas }\end{array}$ & Total & Floor Area & Spacing & Total Units & $\begin{array}{c}\text { Density } \\
\text { (Units/Total Area) }\end{array}$ & $\begin{array}{c}\text { Major Road } \\
\text { Minor Road }\end{array}$ \\
\hline $\begin{array}{c}\text { Tikal city center } \\
\text { (Figure 2b) }\end{array}$ & $\begin{array}{c}240 \mathrm{ha} \\
(32 \%)\end{array}$ & $\begin{array}{c}510 \mathrm{ha} \\
(68 \%)\end{array}$ & $750 \mathrm{ha}$ & $360 \mathrm{~m}^{2}$ & $60-100 \mathrm{~m}$ & 200 & $0.27 \mathrm{units} / \mathrm{ha}$ & $60 \mathrm{~m}$ \\
\hline $\begin{array}{c}\text { Chunchucmil center } \\
\text { (Figure 3a) }\end{array}$ & $\begin{array}{c}62 \mathrm{ha} \\
(42 \%)\end{array}$ & $\begin{array}{c}83 \mathrm{ha} \\
(58 \%)\end{array}$ & $145 \mathrm{ha}$ & $300 \mathrm{~m}^{2}$ & $40-60 \mathrm{~m}$ & 187 & $1.38 \mathrm{units} / \mathrm{ha}$ & $60-70 \mathrm{~m}$ \\
\hline
\end{tabular}

Mayan settlements did not display use of a grid, but this does not mean the dispersed layout was unplanned. Buildings were arranged to align with natural topography and contours, which enhanced the visual aesthetics of the landscape, increased access to sunlight and ventilation, minimized the need for excavation and hence was cost saving, reduced the risk of erosion, and supported protection of biodiversity. Runoff was dammed by 
causeways and canals and diverted towards low-lying areas for irrigation purposes where the landscape was marked with all kinds of natural and human-made reservoirs [40].

(a) Spatial Logic of Mayan Settlements

Urban form refers to the organization of all functional features of an urban area, including streets, buildings, open spaces, and natural areas. The arrangement of these features in Mayan-built areas was shaped by Mayan belief systems and daily activities that in turn transformed and influenced settlement structures [16]. According to Mayan cosmology, the earth is surrounded by supernatural worlds, which can be accessed through the mountains above (arboreal ecosystem), water bodies below the earth's surface (aquatic ecosystem), and the land in between (terrestrial ecosystem). In this respect, the Maya specially regarded the Ceiba tree as symbolizing this 3-part division of the cosmos, representing the underworld, earth, and heavens through its deep roots, high trunk, and spread-out branches, respectively, bringing these worlds together [46]. In other words, the Ceiba tree also represents the unity and interdependence of different ecological systems that make life possible.

Given the importance of cardinal directions, buildings were oriented to maximize the use of sunlight and natural ventilation and sacred buildings were located in such a way as to be visible to the general public [66]. Since north is believed to be where the ancestors and their wisdom reside, important structures are found in the northern zone that was not only suitable for sustainable habitation but also most visible to the surrounding commoner residences [67]. A good example of this orientation is the Twin Pyramid Complex in Tikal (Figure 2a) where the structures are north-south oriented. Mayan settlements displayed the above-mentioned characteristics to create a built environment with the highest level of harmonized living, interconnectivity of all entities with the environment, and acknowledgment of spirituality in nature.

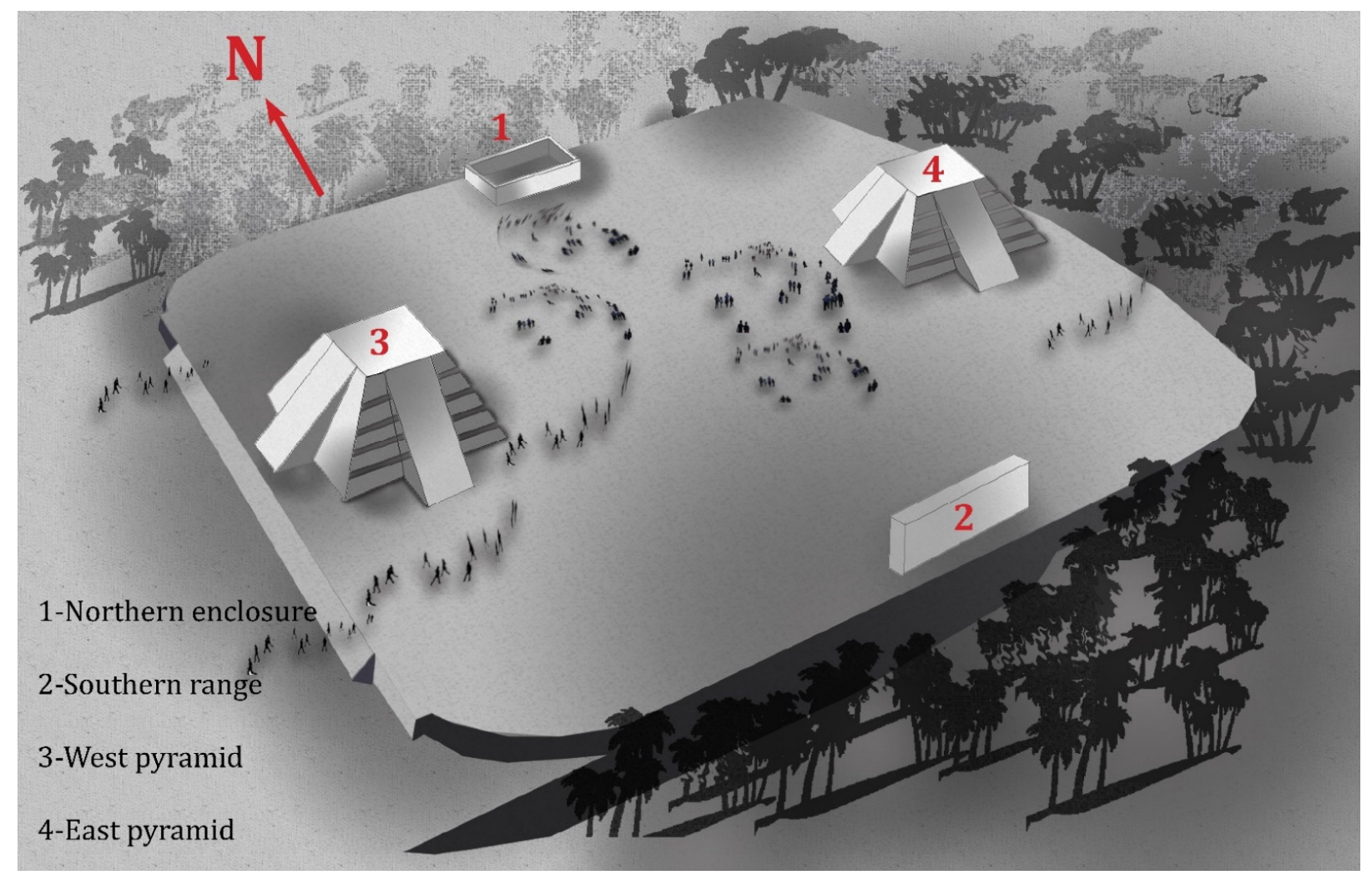

(a)

Figure 2. Cont. 


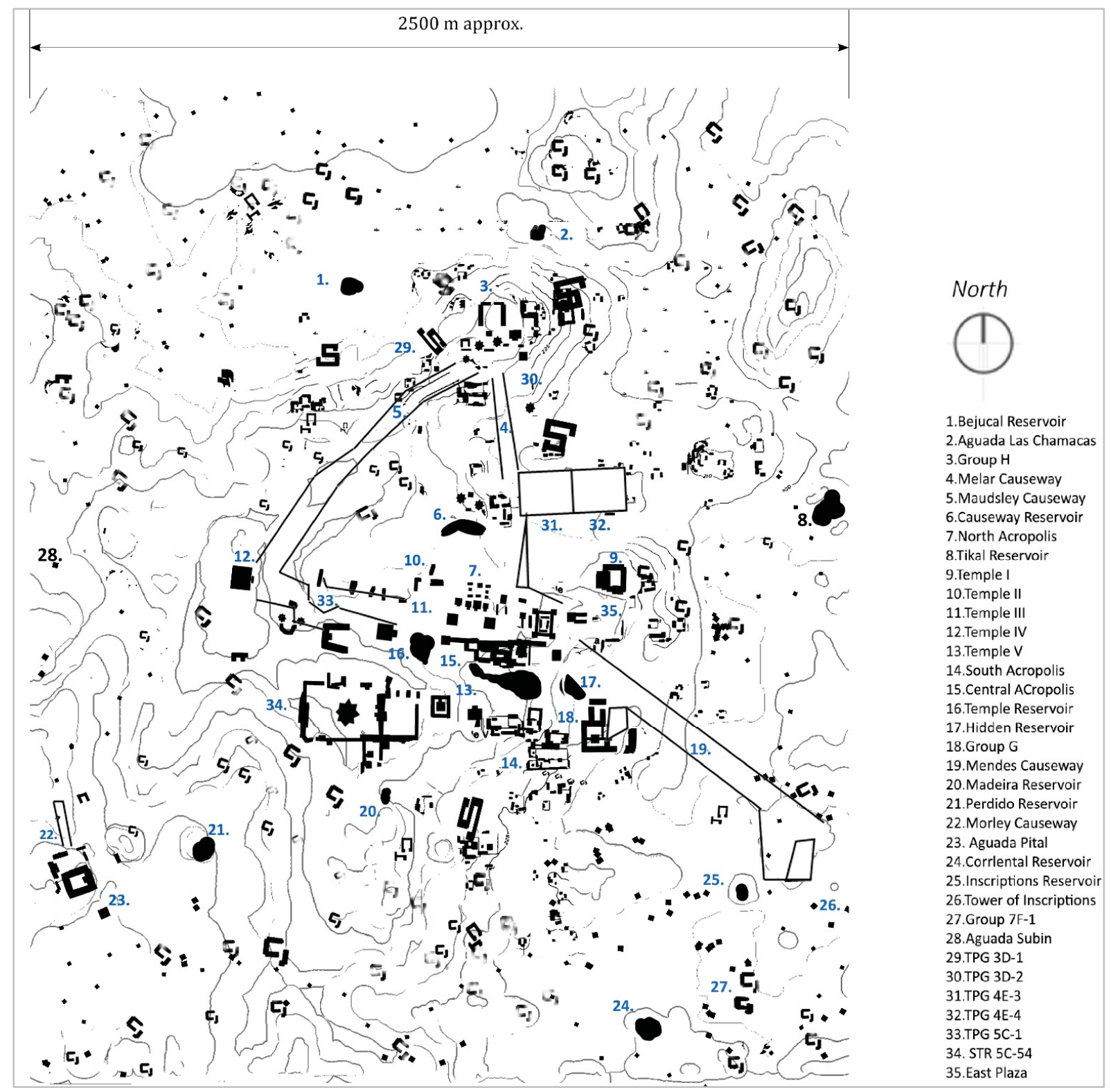

(b)

Figure 2. (a) Twin Pyramid Complex (group 4E-4) at Tikal (Guatemala) having cardinal placement (adapted from Ashmore [33] (p. 201)); (b) Cardinal alignment of the city center acting as an axis mundi connecting spread-out residential units with the underworld as well as the heavens at Tikal, Guatemala (adapted from Ashmore [33] (p. 204)). 


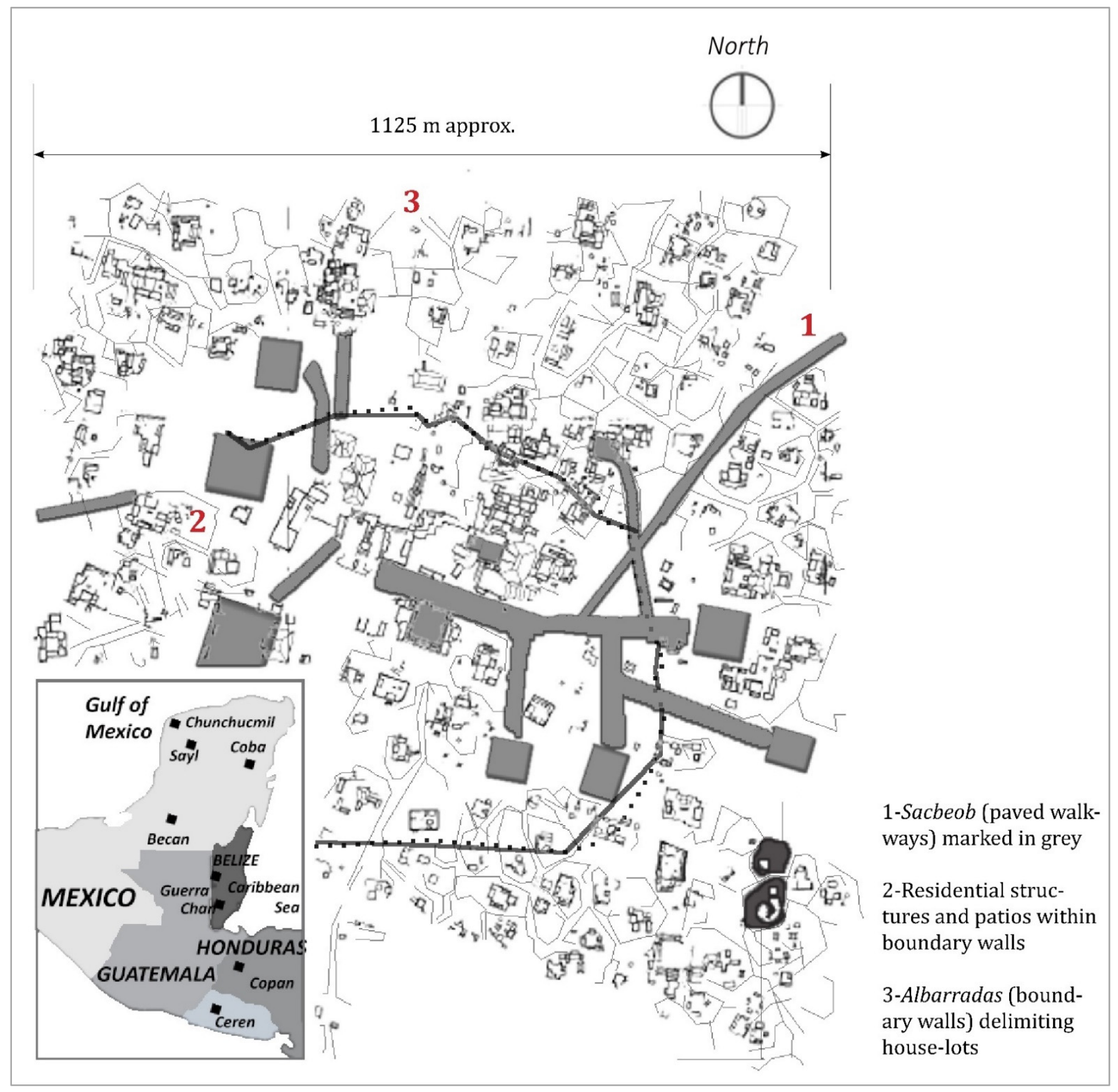

(a)

Figure 3. Cont. 


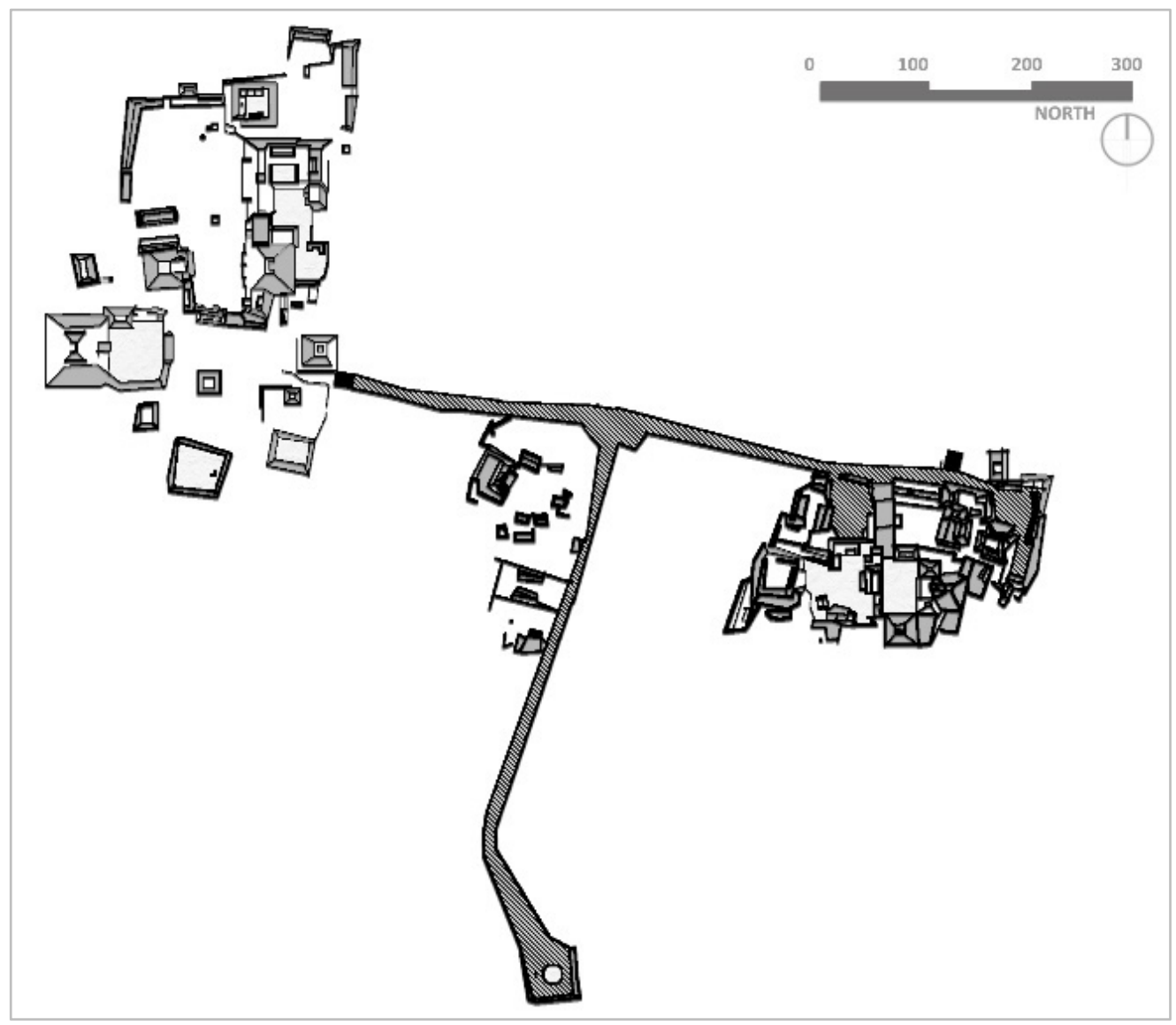

(b)

Figure 3. (a) Sacbeob (marked as a colored grey area) in the center of Chunchucmil connecting house-lots (adapted from Hutson et al., 2007 [68] (p. 466)). (b) Sacbeob in Seibal (adapted from Ashmore \& Sabloff [69] (p. 209)).

The forms of Maya settlements could be informal, but they largely display sensitive harmonization of patio groups (residential and home garden areas), agricultural terraces, raised fields, streets, open spaces, standardization of features according to the locale, mixed and diverse functions, shared interests, and communal uses of facilities which promoted substantial face-to-face interactions [64]. The functional features of a settlement were incorporated into the public realm, including arenas, courts, and accessible markets, thereby fostering inclusion, and increasing social cohesion [61]. In Sayil, for instance, the settlement pattern is more nucleated than some other Maya settlements. Agricultural terraces follow the existing topography while raised fields are an appropriate adaptation of the human habitat under the climatic and geological conditions. The neighborhood open spaces and streets nurture a great sense of community. Since most production, consumption, and recycling took place within or close to the home, walkability is pronounced in Mayanbuilt environments.

The Maya practiced living, working, trading, and gardening within the same locale, giving rise to a better empathy with the environment. Their work and social lives were intertwined with the surrounding nature. Based on the logic discussed above, settlements were modelled as multi-layered (the sky, the earth, and the underworld), connected through time (as represented by movement cycle of Venus, the moon, and the sun), supported by a vertical axis (axis mundi represented by the Ceiba tree-trunk), and divided into four cardinal parts (with an emphasis on a north-south orientation (Figure 2b).

(b) Street Networks

Various buildings in a Mayan city were connected through Sacbeob which were elevated streets constructed for many transportation-related and socio-economic purposes 
(Figure 4a,b). Three types of Sacbeob are commonly found: local, intra-site, and inter-site. Most Sacbeob were roughly between $500 \mathrm{~m}$ and $20 \mathrm{~km}$ long, indicating human-scale and enhanced walkability of a city [70]. Earlier designs did not include parapets, but they were later adopted in various Sacbeob. Their structure was similar to the foundation of any Mayan building, comprising large stones on the edges and grading to smaller gravel towards the upper surface which was finished with powdered limestone. Depending on the location and availability, the backfill for Sacbeob contained organic materials such as snail shells, which highlights waste recycling in Mayan societies.

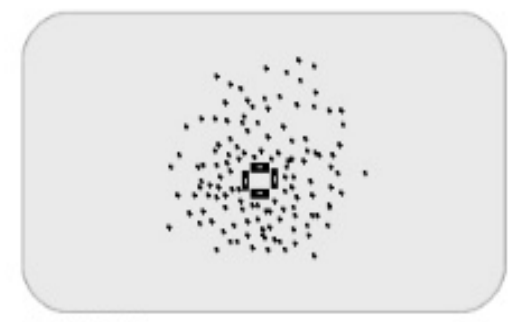

TYPE A

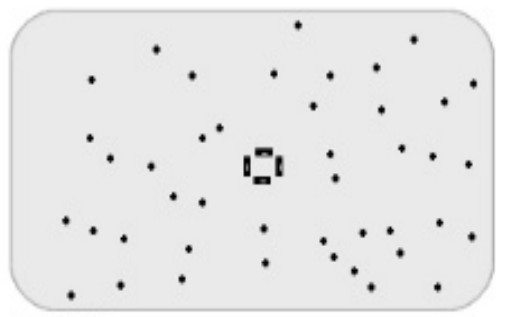

TYPE B

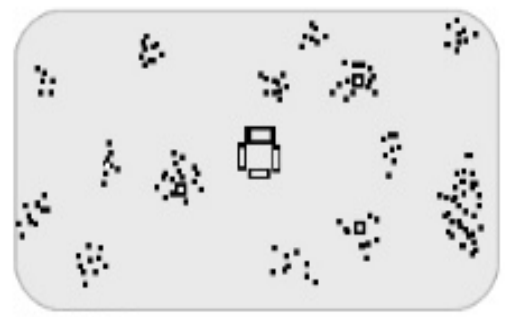

TYPE C

(a)

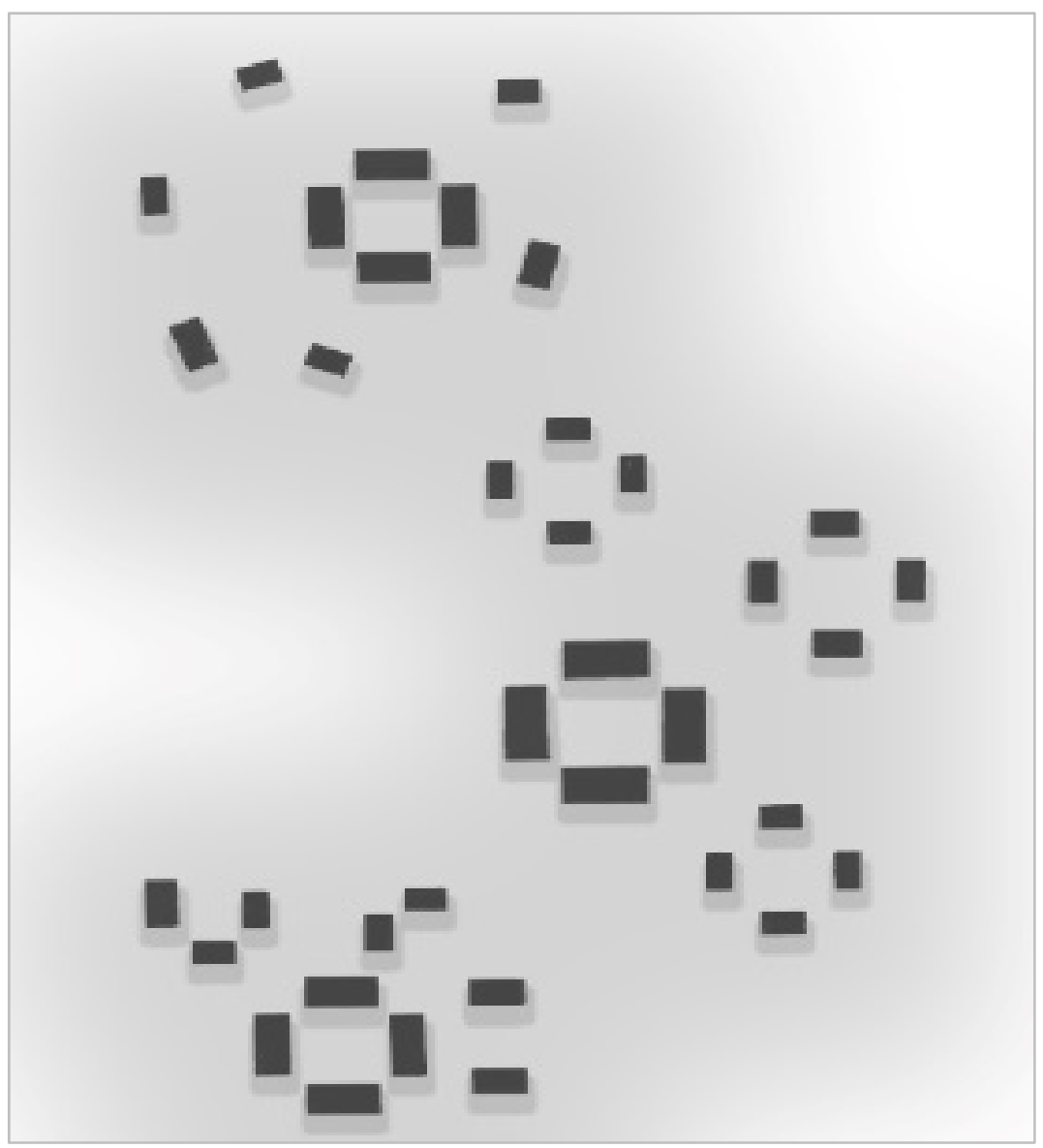

(b)

Figure 4. (a) Schematic drawings for three types of structure clusters in Mayan settlements; dots are house-lots surrounding the religious settlement center (axis mundi) (adapted from Smith [61] (p. 56)). (b) Mayan patio groups showing open patios within built up residences (adapted from Smith [61] (p. 56)). 
Sacbeob served many functions, such as transporting people, animals, and goods. They promoted commerce, multi-level interaction, and processions representing political, socioeconomic, and religious significance [71] through the architectural spaces. Sacbeob also formed the water-retaining edges of reservoirs, directing runoff away from inhabited areas towards natural water collection ponds [70]. By virtue of these Sacbeob and their orientation, a city center acquired an axial position (axis mundi) symbolizing a World Tree connecting the underworld, earth, and heavens in seamless continuity. Collaborative maintenance of Sacbeob (based on green human labor) brought people together and reminded them of a shared memory, sense of place, and religious, political, and environmental order.

\subsection{Building Configuration and Construction}

In several present-day cities, buildings have little regard for local climatic conditions, vernacular construction materials, and environmental sustainability [31]. However, among the hallmarks of Maya settlements is the embeddedness of environmental sustainability in architecture and building arrangement through the appreciation of indigenous knowledge, local climates, and the ecosystem. This Mayan trademark was a result of the prolonged and deep observations and experiences of the society [72]. Climatic conditions and cardinal orientations determined building configuration, architectural form, identity, and functional efficacy, while indigenous building materials lowered building costs. Building construction was based on centuries-old, revered, and adopted techniques that were passed from the ancestors to the current and the future generations.

Space available for housing differs in various Mayan settlements depending on land availability, climate, vegetation, topography, soil condition, and socioeconomic structures. Maya were outdoor people due to the nature of their locale. The resultant lifestyle, daily activities, and architecture, especially in the residential areas, are considered in designing the open spaces within a house-lot and the immediate surroundings. These were important factors in building configuration [73]. Given the nature of a house-lot, a household functioned as a small social group that, in turn, was connected and contributed to the larger population it was a part of. In Tikal, for instance, house clusters are closely spaced but there are large amounts of space between clusters. Continuous causeways may not have been needed; instead, a raised pathway in the landscape might have sufficed for movement [35]. On the other hand, the city of Waka had a nucleated pattern of dense residential quarters, unlike other built environments that have surrounding dispersed settlements.

Various types of building clusters are found in the Classic Mayan settlements (Figure 4a). It was initially thought that each one of them was a residence. However, scholars are now convinced that a certain number of structures were part of a house-lot (Figure $4 \mathrm{~b}$ ). For instance, 2280 structures were studied in Tikal that were later believed to be belonging to 691 groups, each group housing extended families comprising around 25 members [74]. Made of perishable materials and following vernacular style, these buildings fulfilled many purposes, such as sleeping, cooking, washing, processing, and storage [75]. One main difference between a Mayan house-lot and a modern residence today is the former had separate buildings, whereas the later holds all activities under one roof.

The simplicity and sustainability of buildings acquired through vernacular design is reported by Abrams [76]. While discussing the city of Copan during the Classic Mayan Period, the author highlights that new structures were mostly built over the foundations of the old ones. Designs were tried and tested to save time and labor efforts. A structure could be constructed in 100 days or less if it were not elaborate, making sure there was no shortage of labor required for other tasks such as agricultural work. Construction was aligned with the climate; given this, the dry season was the time during which most construction took place. Many other scholars found that construction was accretional, using old structures and available materials; water usage was kept to a minimum; basic design requirements, such as solar and wind movement, line of sight, and utility of the enclosure, fulfilled functional needs; construction details were well known, therefore, unskilled labor 
sufficed for building, reducing time and money $[73,76,77]$. This resulted in the energy saving required for material procurement.

Religious structures were different in design and construction from the residences of the common people. These were highly symbolic, offering spiritual nourishment to the citizens [78]. As discussed above, the ecological and environmental understanding of the Maya was not limited to the earth only; it included the skies and the heavenly bodies. This is corroborated by growing evidence that the orientation of religious buildings is astronomical. Architectural elements used in certain sacred buildings were aligned with the movement of important stars that predicted initiation of certain rituals [67-79]. Apart from fulfilling symbolic and religious needs, these buildings, by virtue of their orientation, helped in measuring time and predicting weather, which was significant for agricultural purposes.

(c) Examples of Ecological Embeddedness of Mayan Settlements

- Coba: Coba was a large urban center during the Classic Mayan era, spread over 30 miles $^{2}$ with a population of approximately 50,000 [58]. Green human labor that comprised thinking and sensitive persons was adopted for all tasks that garnered patience and work ethics. Given this, it is believed that the great 120 -foot-tall pyramid of Coba was built without using wheels, pulleys, and draft animals. Residential buildings were mainly pole and thatch construction; stone was used with care. Terraces marked the residential landscape as the soil was thin and could not retain moisture and nutrients. Fish farming ponds diversified the food supply [80].

- Cuello: Cuello was a Late Pre-Classic settlement famous for its architectural characteristics. For instance, discussing an excavated site in the city, Hammond and Gerhardt [81] found that it consisted of a group of buildings intentionally planned around a patio. Multiple activities are believed to have taken place there, ranging from sleeping, cooking, and storage to burials. This indicates that the site provided self-sufficiency in many respects without having the need to acquire more land to obtain life essentials. The buildings were simple and reparable as local recyclable materials, such as cobble stones, clay, and lime plaster were used for building and repair work. The importance of the patio is signified by the buildings that are oriented towards it, meaningfully marrying the built with the open.

- Caobal: Architecture and construction appear to have had a social and political effect on the population of Caobal, such as building a spirit of community and maintaining connections with past generations and their experiences. The amount of domestic refuse found at different sites hints at the collaborative aspect of construction that, among many other factors, encouraged social sustainability. It appears that involvement in the construction process was as important as the output. The built environment also displays ecological knowledge and environmental stewardship. This is evident from practices such as adoption of reusing, recycling, and selecting earthen and local materials and keeping technology simple. Given the above, the built environment in Caobal became a container of social and environmental memory for future generations to follow [34].

- Chan Noohol: Located in the upland of the Mopan and Macal Rivers, this settlement comprises seven farmsteads that are 50-70 m apart. Every farmstead has a dedicated area for cultivation created on a non-orthogonal terrace. Both the terrace and the delimiting low-height retaining wall follow the existing topography that points towards site familiarity and the respect that the residents had towards what was already present. Existing bedrock was used as the foundation for structures, reducing foundation work and material required. This also helped to raise the level of the structures naturally. Local materials were used, such as chert cobbles and unshaped stones. New landscape features were created where the previous inhabitants had indicated they ought to be placed. This ensured cultural continuity and adherence to the site's demands [82].

- Copan: Abrams [76] shares interesting information about the construction of a religious site and its structures in Copan. The construction work appears to be a single 
event requiring less labor and time because it was completed via the communal efforts of both men and women. The capability of the residents made them efficient if not highly skilled laborers. The author estimated that the construction was most probably completed with a special workforce of 40 persons employed on a yearly or half-yearly cycle, and about 370 non-specialized workers for about 60 days.

- Chunchucmil: Located in north-western Yucatan, Chunchucmil had a population of about 35,000 spread over 20-25 km² during the Classic Period. Dense house-lots delimited by albarradas (shared boundary walls) and chichbes (winding causeways) were distinguishing features here (Figure 5). The average house-lot size was approximately $4200 \mathrm{~m}^{2}$ containing open spaces of approximately $3595 \mathrm{~m}^{2}$. Although the city's location does not support intensive agriculture, the open house-lots still contained areas for climatically and geologically suitable cultivation that needed little tending. The trees in the house-lots imitated regional forests and provided economic benefits. Apart from residences, open spaces within house-lots were also used for other activities, including handicrafts, animal keeping, apiaries, processing, corn storage, rituals, burial, washing, toilets, and dumping organic waste (Figure $6 \mathrm{~b}$ ). The low height of the albarradas suggests strong social networks and sustainability. Existing materials and past platforms were used for the foundations, whereas the superstructures were made from perishable materials $[68,83]$.

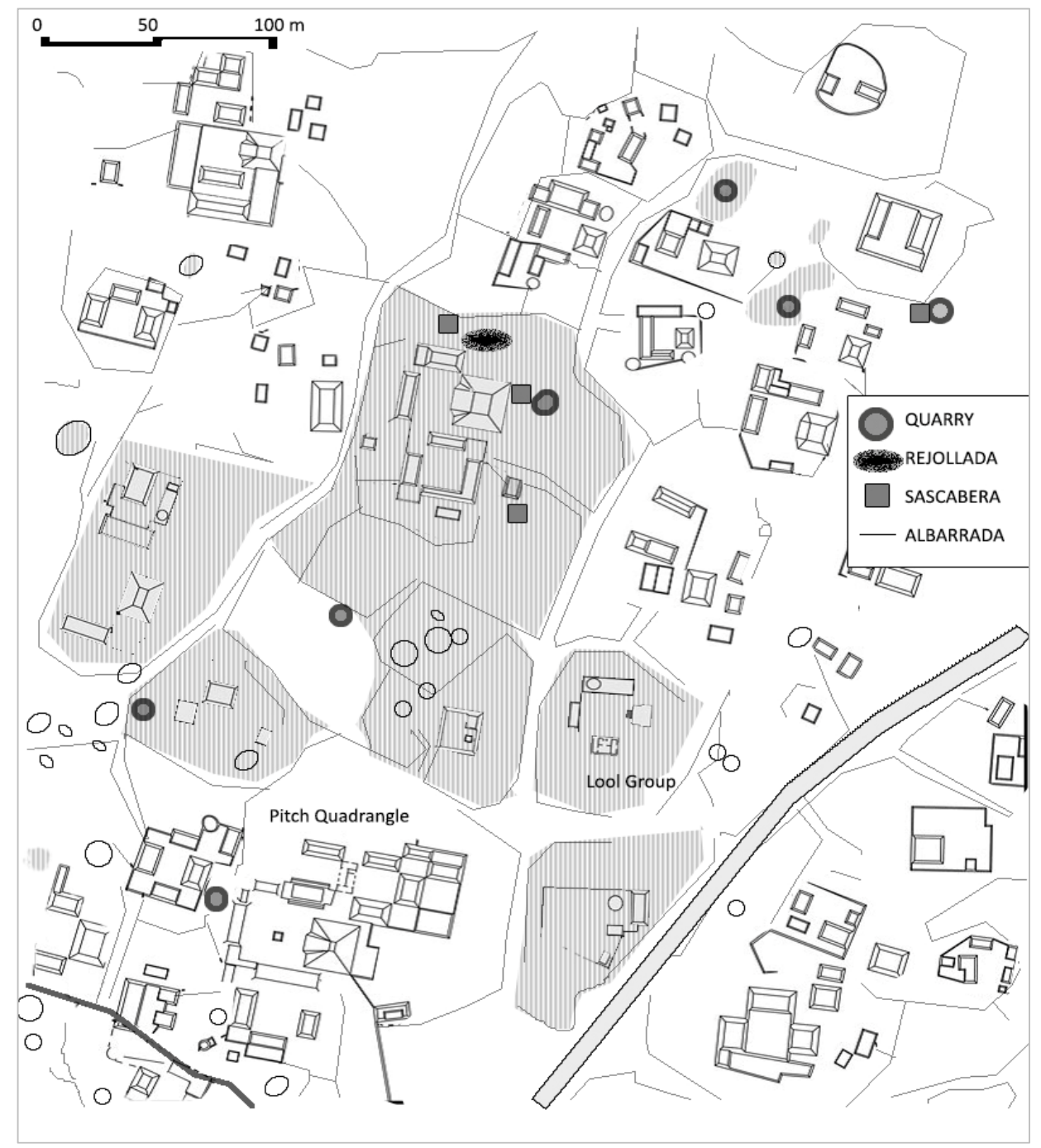

Figure 5. Schematic drawing showing homes, clear area, intermediate area, and garden area in Chunchucmil (adapted from Hutson et al. [68] (p. 444)). 


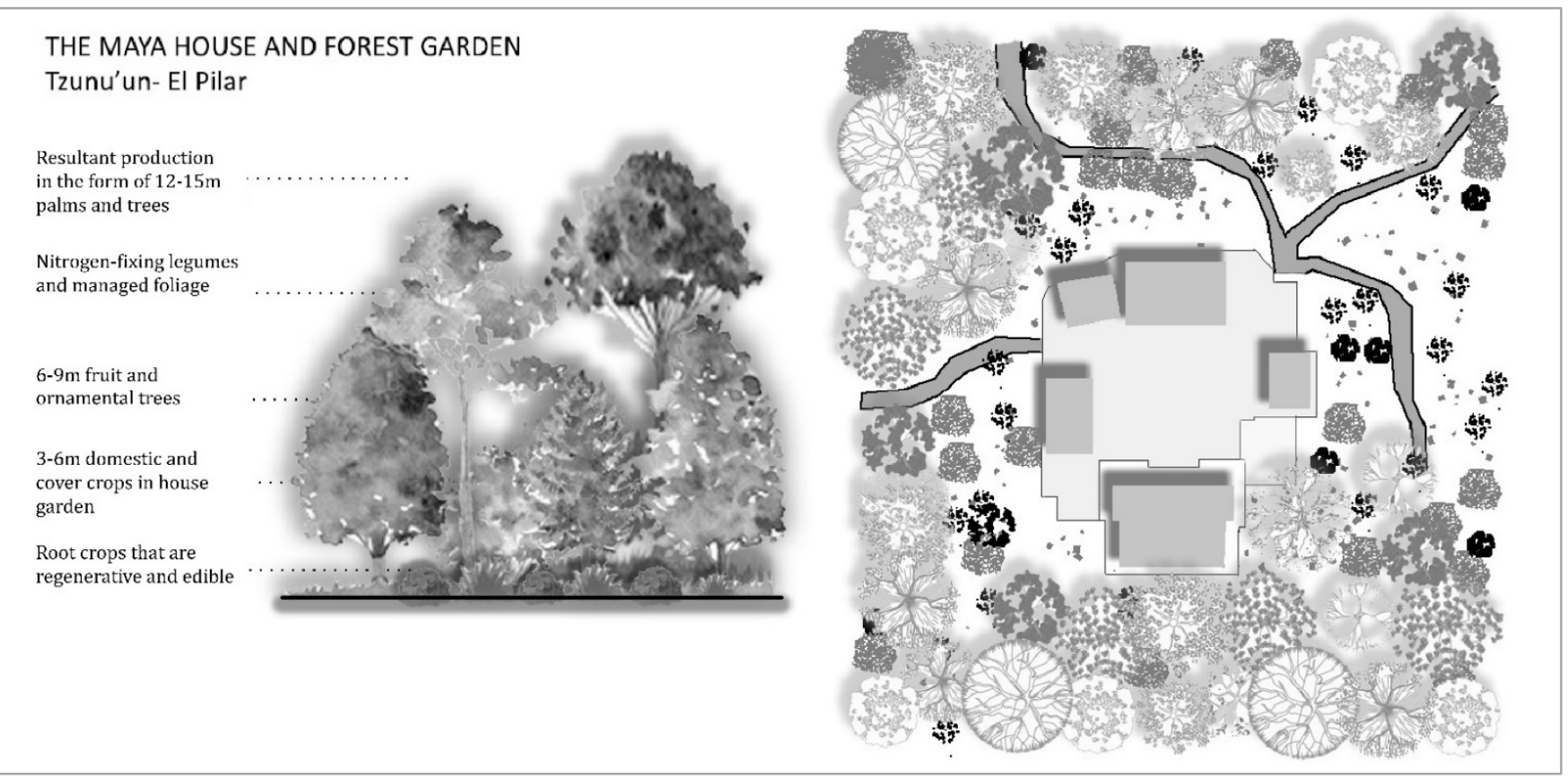

(a)

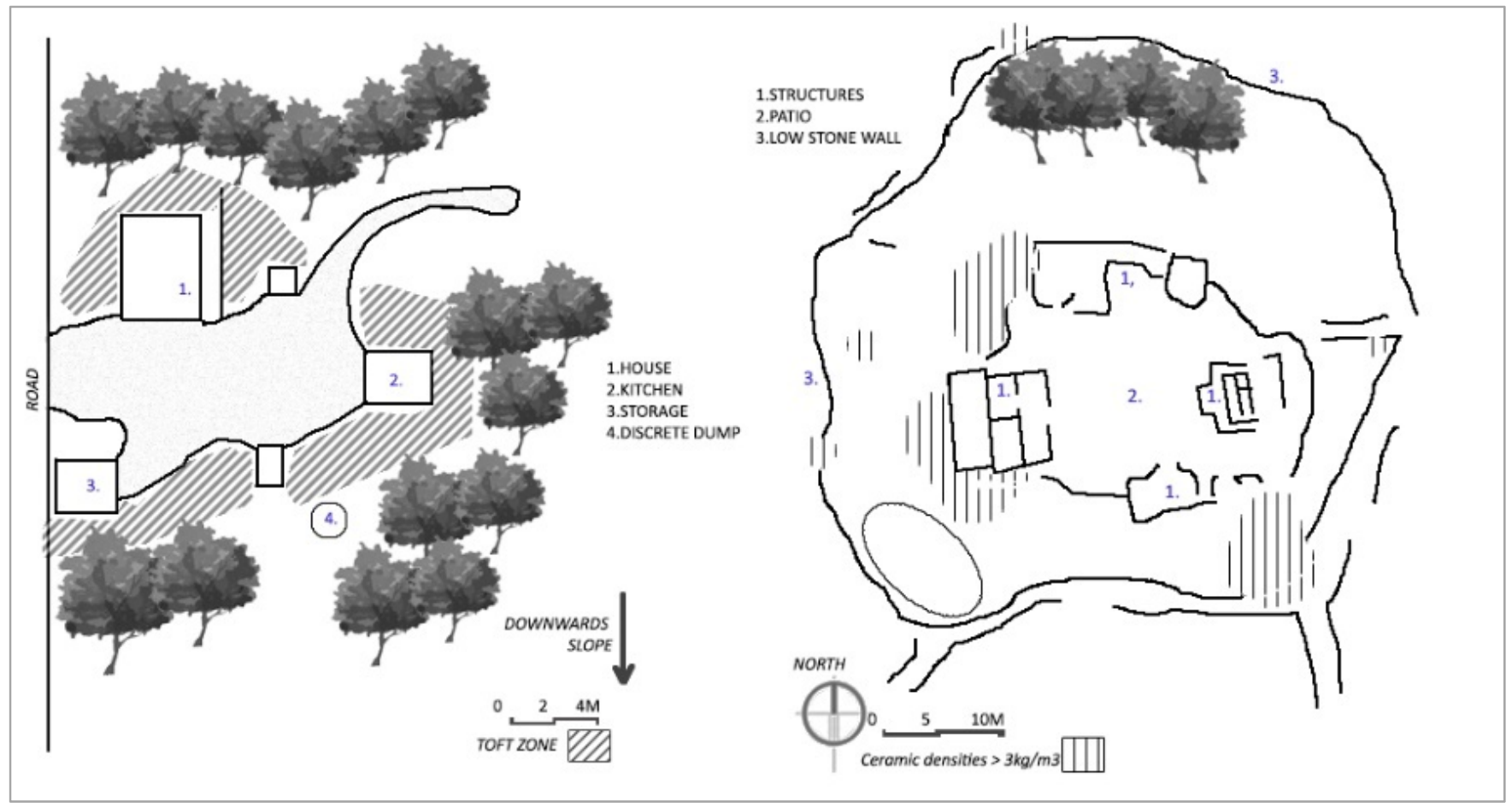

(b)

Figure 6. (a) Forest garden and the Maya House: Mesoamerican Research Center today following ancient Maya house garden techniques with a variety of plants and trees offering shade and nutrition (adapted from Ford [84]). (b) Map showing residential groups in Chunchucmil with home gardens and other miscellaneous functions (adapted from Halperin and Foias [85] (p. 13).

- El Palmar: The abundant presence of the Golden Section in nature and its recognition and application by the Maya points towards their connection with nature and all its constituent ecosystems. One of the examples of this fact is given by Doyle [86] who, after studying selected buildings in El Palmar, makes the case of the use of the Golden Section by the Maya in urban and architectural works. The author contends that, even 
though historical continuity and cardinal alignments were factors in determining the spread of the group under discussion, the usage of $48.5 \mathrm{~m}$ by $78.5 \mathrm{~m}$ Golden Section squares is also evident while sizing the building plans. The Golden Section is also applied to work out platforms for other buildings and open spaces; for instance, the size of the Triadic Group in El Palmar is $100 \mathrm{~m}$ by $160 \mathrm{~m}$ which, again, is a Golden Section square. Interestingly, the Golden Section was also used to determine lot sizes for Milpa farming.

- Joya de Ceren: Living in sustainable houses constructed with wattle-daub walls and thatch roof, the residents of this village also exhibited remarkable knowledge of the climate, soil, and plant biology. Intensively cultivated gardens surrounding the houses contained a variety of plants and trees, which provided food as well as shade and demarcation for the house-lots. The agricultural yield from the house gardens as well as the infield maize crop not only ensured self-sufficiency, but also provided enough surpluses to be exchanged for valuable goods [64].

\subsection{Urban Agriculture and Home Gardening}

The basic unit of Mayan settlements comprised not only residential compounds and neighborhoods, but also autonomously managed gardens, along with their surrounding farmlands. The amount of tree cover helped control soil erosion, while urban green areas connected the civic and ceremonial functional zones that linked to the residential areas [87]. Urban agriculture depended on diverse farming practices based on the local ecological, socioeconomic, and political situations. The fact that the agricultural landscape was a part of the Mayan-built environment is archaeologically evidenced by the variations in the identity of settlements and the people that lived in various regions.

For instance, even though infield agriculture is quite a common feature, nuances exit in the way it is made part of the built environment in different communities [88]. This distinction is a result of adaption required for the semitropical climate, varying terrain, and soil conditions [50], and the presence of diverse species [89]. Environmental feedback was instrumental in the decision-making process regarding how to modify the land for agriculture, habitation, and gardening. In this respect, terraces embedded in the landscape were particularly helpful in retaining moisture in the ground as well as preventing erosion of soil that was already thin [51]. For example, in Tikal, agricultural terraces were present in almost every household that had access to two to four acres of land [35].

Apart from water retention, terracing also provided a suitable flat surface for cultivation, nutrient penetration, and residential structures. As evidenced in Tikal, sometimes berms were also constructed to delimit terraces, provide raised surfaces for walking if needed, divert water to low-lying bajos (seasonal wetlands), and prevent silting [46]. Since the maintenance of these terraces required collaborative intensive labor, population growth supplied an essential human resource [90]. Thus, settlement patterns integrated with the agricultural land became a strong norm unifying the Maya in their common social and economic undertakings.

The favorable climate encouraged outfield agriculture in settlements such as Coba, therefore, house-lots relied less on home gardens. In comparison, Chunchucmil was dependent on infield agriculture as demonstrated by the presence of larger house-lots that had rejolladas and sascaberas (laterally dug chambers on the dry side of a sinkhole in the karst ground within the lot boundary) [91]. The combination of infield and outfield areas is another land-use pattern found in Mayan settlements. This assisted the Maya in dealing with unpredictable weather and crop yield. Infield areas were close to home and occupied by households as a primary base. Distant outfield areas, on the other hand, complimented the infield by becoming secondary cultivation and residential areas in case there was a need, depending upon the weather conditions [44].

Milpa farming is another instance of sustainable agricultural practice where the landscape setting within a built environment was purposefully and periodically changed to ensure sustainable agricultural yield while maintaining forest cover. This is a method 
where certain crops are grown on a rotating basis through transitional stages, providing control and soil enrichment. The Milpa cycle, shown in Figure 7a has three main phases:

- Looking for forest clearance mainly caused by cyclones and preparing the land for cultivation.

- Introducing crops that are rotational, diverse, and receive enough organic fertilizer as well as soil nutrients. This gives rise to a landscape which is a mix of varied crops, wild plants, and carefully selected trees.

- Leaving the land fallow for several years after a fixed cycle of cultivation to regain its original vegetation and nutrients. This is conducted by replanting seeds from the mature neighboring trees and crops.

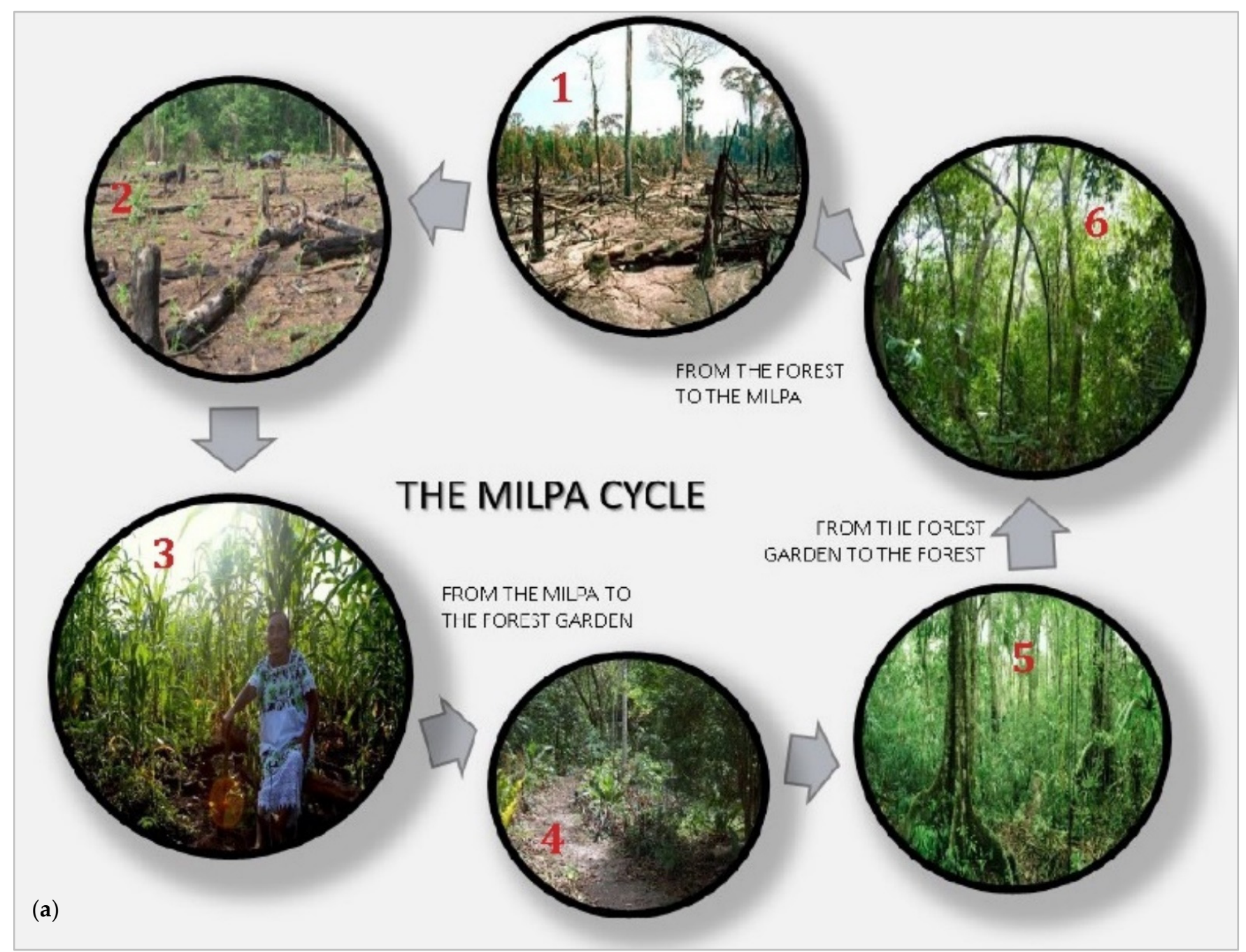

Figure 7. Cont. 


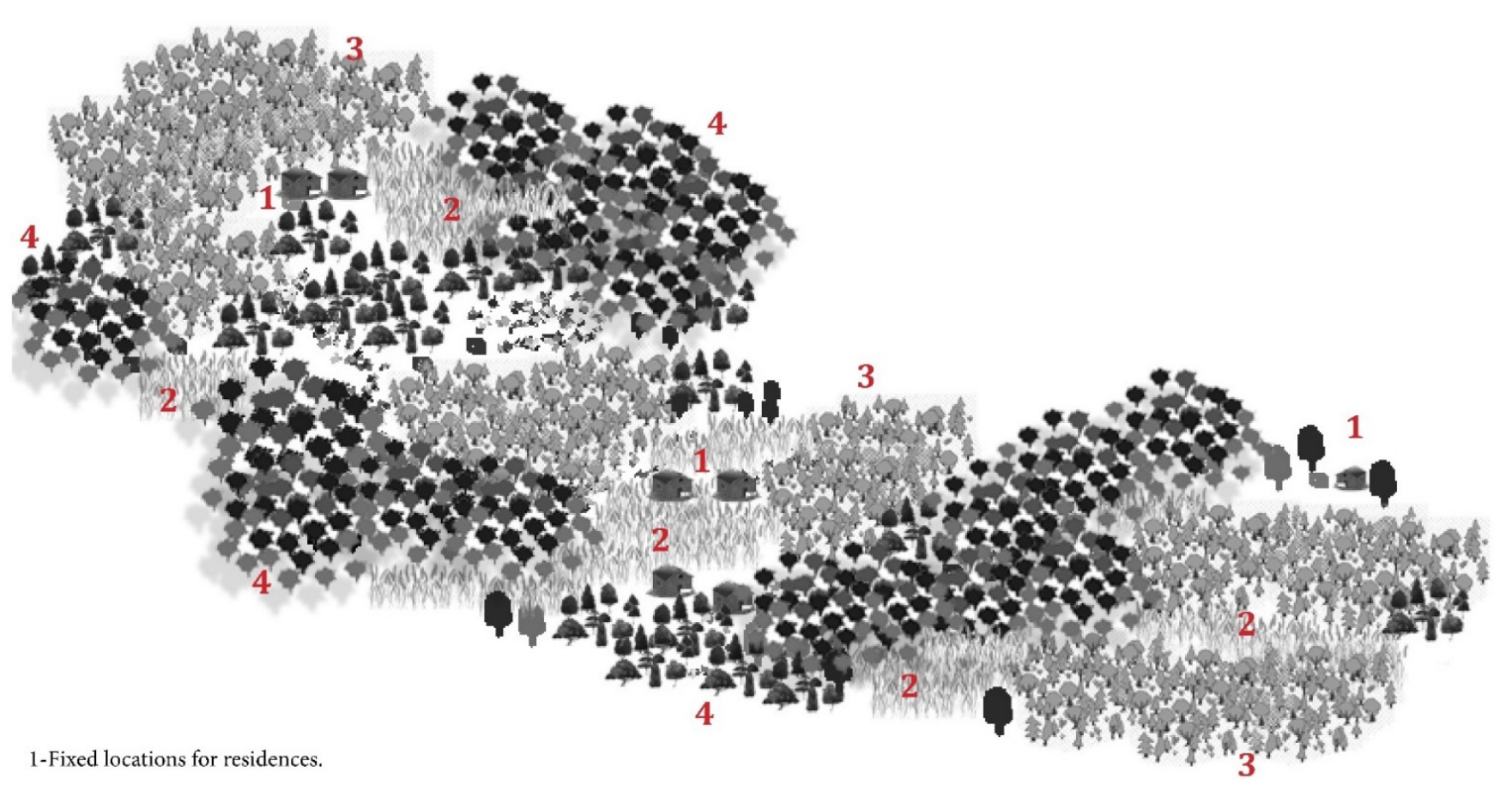

2-Crop cultivation on fertile land that has been created by forest clearance.

3-Land left fallow to become forest again after multiple harvests so that it regains its fertility.

4-Managed forests whose location is changed over time to create space for crop cultivation.

(b)

Figure 7. (a) Schematic drawing for Milpa cycle showing mature forest to agricultural field (labels 6, 1, 2, and 3 counterclockwise) to long perennial/ecological succession (labels 3, 4, and 5) and back to forest again (labels 5 and 6) (adapted from Ford \& Nigh [63] (p. 185). (b) Landscape defined by Milpa cycle (adapted from Bates [92]).

In short, the Milpa cycle is moving from forest to Milpa, followed by Milpa to forest garden, and finally, from forest garden back to the original forest (Figure 7b). Given these ecologically thought-out rotations, the built environment retained what already existed in the form of landscape [90]. Furthermore, diverse interactions with their given locales helped the Maya to spread out risks through house gardens, infields/outfields, Milpa farming, and forest management [90].

Home gardens were also significant green infrastructure that enlivened workplaces and residences. These lent meaning to such spaces and stored memories for future generations to relate and add to. Given the collaborative nature of the work required through human labor, home gardens advanced social sustainability [82]. Apart from being a symbol, home gardens were also utilitarian in nature, providing food and medicinal herbs, functioning as sunshades and windbreaks, and capturing and storing carbon [60-82]. According to the ethnographic research, lot sizes for intensively maintained home gardens were approximately 2.28 ha [50]. This diverse and environmentally responsive land use was complemented by less intensive outfields cultivated by the same family. Sayil, located in the Puuc, region presents a classic example of a garden city, owing to favorable soil conditions [93]. These gardens were dedicated to growing domestic, edible, and cover crops such as palms and cocoa plants requiring frequent and intensive tending [94]. Other plants were nitrogen-fixing and ornamental-shading legumes.

Home gardens are a noticeable feature of the Mayan settlements that exist even today [37,88,95-99]. In this respect, archaeological site 272-025 (also known as Tzunu'un) in the Mayan city of El Pilar presents an illuminating example of recreating a Mayan home garden in the present time. Maya forest gardening was interpreted by inviting traditional Mayan farmers and gardeners to implement their practices on site. Figure 6a shows the 
nature, profile, and location of vegetation on this site that provides food, climate control, and soil conservation.

(d) Examples of Home Gardens in Maya

- Guijarral: Home gardens that are close to the residences formed one component of the settlement pattern in Guijarral. This kind of garden is complemented by distant infields and outfields where major crops were cultivated. This purposefully embedded the population spatially, environmentally, economically, and spiritually in the built environment [87].

- Papaloapan River: This urban settlement was dispersed over large area. Engagement in intensive and extensive home gardens and contiguous infields made this settlement look like a 'Garden City'. Extensive distant outfields were cultivated rotationally and added resilience and risk mitigation [60].

- Sayil: The population in Sayil practiced intensive home gardening within city's bounds, making it another precedent of a 'Garden City'. Agricultural input was provided through green human labor that was essentially collaborative. Organic refuse, mulch, and human and animal waste were used as fertilizer that did not damage the soil. The presence of small garden lots indicates autonomy at the lower social levels.

\subsection{Water Conservation}

Water and its conservation were critical to the Maya given its scarcity, especially during the dry season. Its conservation and safe discharge to other areas throughout the year hints at their advanced knowledge [43]. As such, features such as aguadas (natural or humanmade land depressions), bajos, chultans (underground water storage tanks in residential lots), berms, and dams formed essential elements of the Mayan-built environment [43], providing enough water for household and agricultural functions over the course of the year, especially the long annual drought [89]. Water ponds were multifunctional, offering ecological, spiritual, social, and economic benefits.

During the Late Pre-Classic Period (400 B.C-250 A.D.), some settlements were located close to existing natural depressions that were carefully reformed to collect the runoff from natural watersheds. For instance, in Sayil, underground water tanks known as chultunes form a noticeable feature of the built environment. The ensuing Classic Period (250 A.D.-950 A.D.), on the other hand, marks a change in water conservation in many sites such as Calakmul and Tikal. At those sites, important buildings and reservoirs were placed on higher altitudes, for instance hill summits. The water conservation profile during that period was convex, contrasting with the concave one adopted in the Late Pre-Classic Period (Figure 8). The impermeable pavement around sacred buildings on the summit guided rainwater towards large reservoirs. Canals from these reservoirs then transferred water to the dispersed farmsteads and their peripheral bajo reservoirs. However, this strategy differed for locations where there was abundant rainfall $[40,89,100]$. For instance, in settlements such as Copan and Palenque, water was not collected at the summit but diverted away to avoid damage due to flooding [36]. 

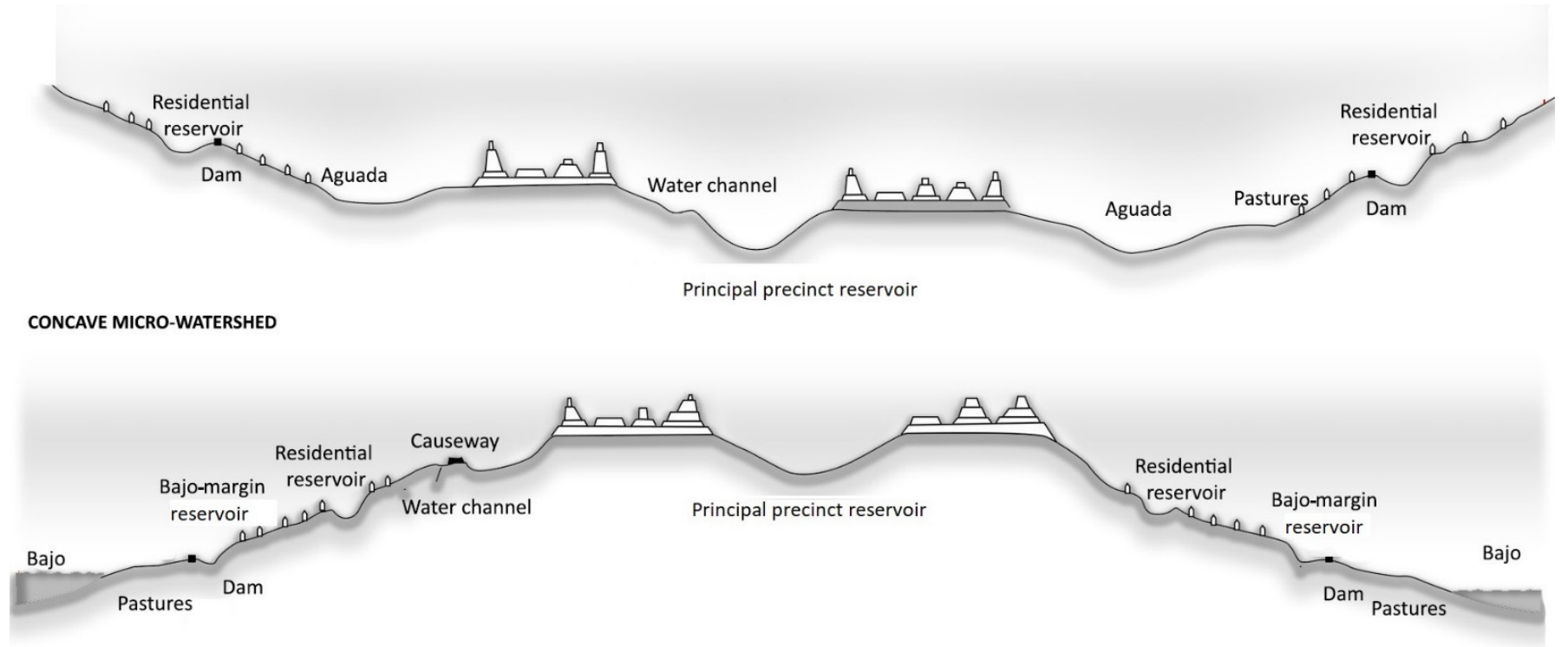

CONVEX MICRO-WATERSHED

Figure 8. A change from concave micro-watershed (top: Late Pre-Classic Period) to convex micro-watershed (bottom: Late Classic Period) (adapted from Scarborough [101] (p. 140)).

(e) Examples of Water Conservation by the Maya

- Tikal: The central district in Tikal was placed on the summit of hills where watersheds were artificially modified to manage runoff. Six catchment reservoirs are located on this summit on an area of 6 to 9 ha that eventually led the runoff to the low-lying bajo and aguada reservoirs. The summit reservoirs could store approximately $900,000 \mathrm{~m}^{3}$ of water, which was adequate for daily needs as well as replenishing the bajos (Figure 9). These reservoirs had raised causeways on their edges to dam water and direct it towards naturally occurring swamps [48] (p. 6). Floodgates were provided under the causeways to release water into the bajo-margin reservoirs for irrigation and drinking purposes. Pozas are another form of small-sized ponds within house-lots that were filled by the central water reservoirs [90].

- Yanxohcah: Located in the Central Uplands of the Yucatan Peninsula, this city is another example of skillful water conservation by the Maya. Here, many land depressions of around $20 \mathrm{~m}^{3}$ have been identified through LiDar analysis [102] (p. 293). Since the soil was porous, the local reservoirs were lined with lime plaster to prevent water seeping into the ground. Water was received in these reservoirs through runoff flow under gravity and used for religious and agricultural purposes [100].

- Cayo: Apart from storing water for domestic purposes, the dam in Cayo also appears to have been used for breeding freshwater invertebrates that were a source of protein. This fact is confirmed by the presence of snail shells. The dam was strategically placed between converging hills and has a capacity of around $300 \mathrm{~m}^{3}$. The retaining wall for the dam is well anchored to the bottom by being thick at the lower end while tapering to a slimmer section towards the top side [103] (p. 151). This indicates the developed understanding of the Maya about the way water exerts pressure on the enclosing surfaces of a dam.

- Copan: It was ecologically challenging for people to live in Copan due to the high rate of rainfall. Given this, water collection and dispersal were equally important to avoid flooding and soil erosion. To address this challenge, exceptional familiarity with the climate and hydrology played a key role. Water conservation undertaken at Copan further considered local hydrology, population density, site planning and architecture. 
Effective water dispersal was thus achieved through the design and implementation of causeways, splashboards, roof drains, paved patios, stucco channels, substructure, and subterranean conduits [36].

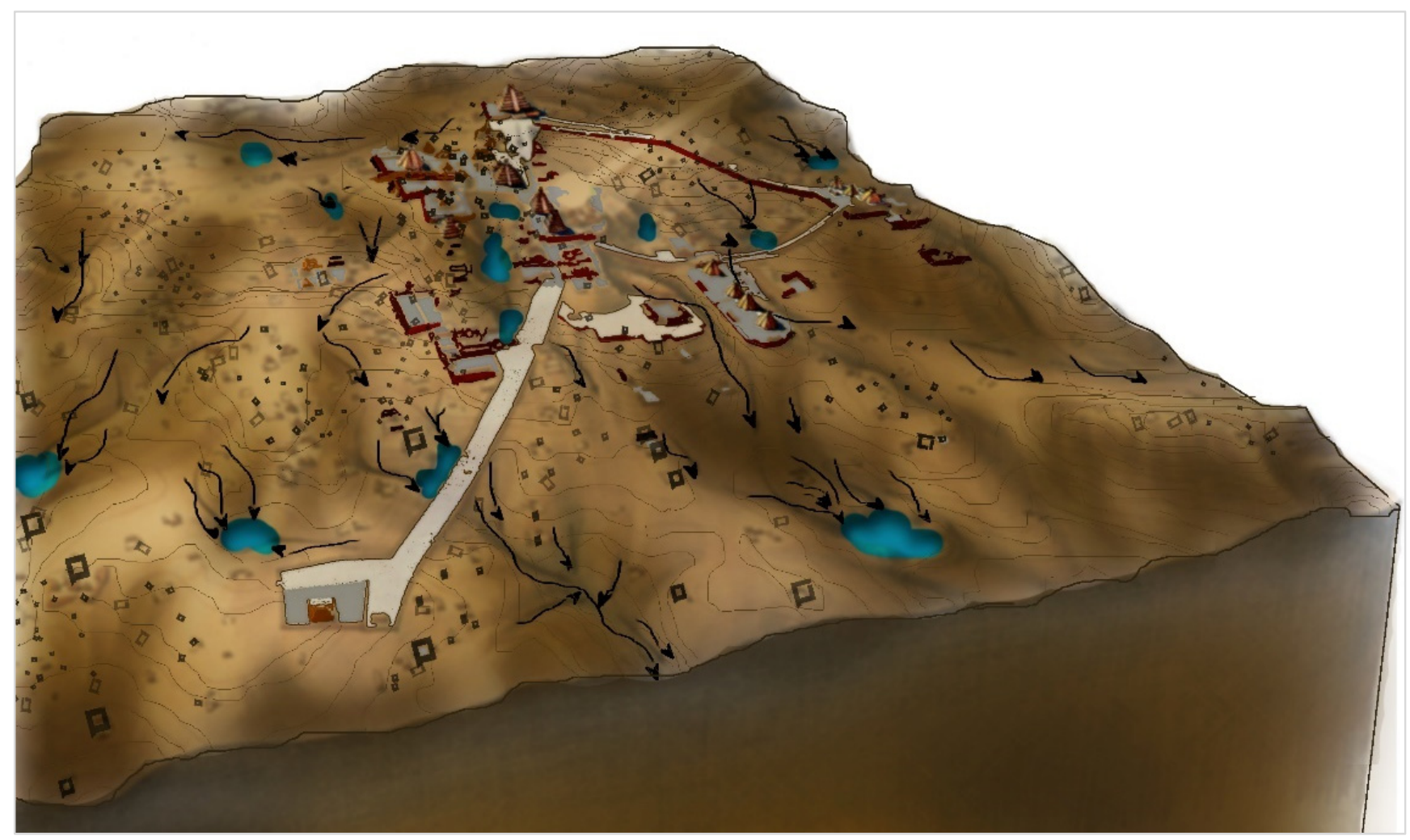

Figure 9. Water management in Tikal: The image shows the flow of water under gravity from the watershed created on the hill's summit. The water is then stored in the low-lying bajos (natural and human-made water reservoirs) that dot the landscape for use by the common people especially during the dry season. This shows an increased understanding by the Maya of their climate and terrain (adapted from Lucero \& Gonzalez Cruz [48] (p. 6)).

\section{Discussion: Lessons toward Mitigating Current Urban Sustainability Challenges}

This study of the Classic Mayan-built environment highlights the ecological understanding and sustainable practices of the people that shaped their settlements and helped them survive for many millennia. Table 3 demonstrates that the environmental sustainability practices of the Maya are strongly related to the six principles of ecological embeddedness identified by Turner et al. [24]. The next sub-section discuses some key lessons that can be drawn from the ecological wisdom of the Maya that can improve the planning and building of contemporary cities.

\subsection{Settlement Patterns}

The Maya understood well environmental components, their interdependencies, and how to work with them for mutual benefit. The results of this are manifest at all levels, such as laying out buildings and connecting various areas within a city. The societies identified with and were embedded in the land they occupied, coevolving with all the components of their context. The people lived, traded, worked, farmed, played, and socially interacted in the same place. These activities, plus the culture and history, sustainably functioned and coexisted with the various components of the ecosystem, including the land, plants, animals, and sustainable lifestyle. The Mayan-built environment comprising residences, agricultural terraces, and managed forests was much more than just a means of getting food, clothing, and shelter. It was a concentration of diverse activities such as occupational specialization, production in surplus, individual and community interdependence, and 
art and culture. Settlement patterns in many Classic Mayan settlements corresponded with diverse activities that were ecologically friendly: the density fostered walkability, causeways are multi-functional, and site development was incremental, ensuring reuse of existing structural elements.

Table 3. The extent to which the six principles of ecological embeddedness were met by the Mayan-built environment.

\begin{tabular}{|c|c|c|}
\hline \# & Six Principles of Ecological Embeddedness [24] & Examples of Ecological Embeddedness of the Mayan-Built Environment \\
\hline 1 & $\begin{array}{l}\text { Interconnecting and rotating all entities in an } \\
\text { environment }\end{array}$ & $\begin{array}{l}\text { - Ceiba tree symbolizes connection of all entities present in an area. Therefore, } \\
\text { interdependence of different ecological systems is recognized. Another instance of this is the } \\
\text { cosmic interconnections with earthly undertakings, such as the beginnings of rituals and } \\
\text { cultivation periods. These connections are of demonstrated practical value. One more } \\
\text { interesting example of interconnectivity of different elements is purification of water to make } \\
\text { it drinkable. This is conducted through the interdependent working of algae, lime mortar, } \\
\text { fish, and water lilies living together in a water reservoir. } \\
\text { Time is perceived as cyclical/rotational. Phases in personal and practical life are predicted } \\
\text { based on this perception, preparing one for future events. In everyday life, this is reflected by } \\
\text { the rotation of crops and forested areas through Milpa farming, ensuring reliable subsistence. } \\
\text { Another instance is basing the urban land-use concept of infield and outfield areas on } \\
\text { rotation of intensive and extensive crop cultivation that provides sufficient agricultural yield. } \\
\text { This also helps spread out risks and develop resilience in the built environment. }\end{array}$ \\
\hline 2 & $\begin{array}{c}\text { Environmental feedback and sustainable resource } \\
\text { harvesting and reuse }\end{array}$ & $\begin{array}{l}\text { - The degree to which foreign plants can be cultivated is based on environmental feedback. } \\
\text { This fact is also visible in the settlement patterns that reflect the surrounding landscape. } \\
\text { Carrying capacity is increased, working in collaboration with all elements present in an } \\
\text { environment and their response to human intervention. Another example of this principle is } \\
\text { that complete deforestation is not observed. The local climate is controlled through } \\
\text { maintaining forest cover. Information for its success or failure is competently received } \\
\text { through environmental feedback and responded to on time. } \\
\text { Water conservation through thoughtful management is vital and a permanent feature of the } \\
\text { built environment. The same thought is applied to waste that is reused or recycled; for } \\
\text { instance, human and animal waste is reused as fertilizer, broken pots and other items help in } \\
\text { backfilling foundations for residences and sacbeob. Sustainable use of resources is also } \\
\text { evidenced in houses for commoners that are made from perishable and recyclable materials. }\end{array}$ \\
\hline 3 & Knowledge accumulation and transfer & $\begin{array}{l}\text { - Occurrence of environmental feedback ranges from a few weeks to centuries. Therefore, } \\
\text { knowledge acquired by the previous generations is extremely important, as it contains } \\
\text { information about previous feedback and their cycles. Given this, knowledge is accretional } \\
\text { and not only enriches the present generation, but also becomes a valuable source for future } \\
\text { generations. } \\
\text { - Human labor allows for a direct and effective knowledge transfer. }\end{array}$ \\
\hline 4 & $\begin{array}{l}\text { Respectful and collaborative approaches to human } \\
\text { activities }\end{array}$ & $\begin{array}{l}\text { - The Mayan-built environment is an anthropogenic landscape located in its geography. } \\
\text { However, this is far from colonization of nature; the resultant Mayan habitat is a } \\
\text { collaboration between humans and nature marked by reciprocity and respect. } \\
\text { Since environmental feedback is received by the common people present on ground, their } \\
\text { role is crucial if the society is to survive. This results in the promotion of bottom-up policy } \\
\text { decision making. Therefore, creation of the built environment is based on green human labor, } \\
\text { which brings people together and encourages social sustainability. }\end{array}$ \\
\hline 5 & Associating oneself as a part of their ancestral land & $\begin{array}{l}\text { - There is one spirit that dwells in all human and other-than-human entities. This means the } \\
\text { land and its inhabitants share one soul that bind them together. Given this, culture develops } \\
\text { from the local physical environment, its constraints, and opportunities, as all share one soul. } \\
\text { Meaningfulness found in the built environment is due to Mayans' association with their } \\
\text { context. } \\
\text { Ecological knowledge varies from region to region. Migrating to a different land would mean } \\
\text { reinvesting centuries to acquire new knowledge. Therefore, survival in the ancestral land, } \\
\text { even during the worst environmental events such as droughts is more likely than elsewhere, } \\
\text { given the Mayans' association with their land. Amongst other factors, burials provided a } \\
\text { strong emotional and spiritual tie to the land. The Mayans gathered around the graves to } \\
\text { seek inspiration and guidance from the spirits of the deceased. }\end{array}$ \\
\hline 6 & Acknowledging spirituality in nature & $\begin{array}{l}\text { - The way an environment and all its constituents come together to make life possible was } \\
\text { awe-inspiring for Mayans. The spirituality derived from this is that there is a supreme soul } \\
\text { that oversees and guides life. One example of this is the pronounced visibility of religious } \\
\text { centers in the Mayan-built environment. } \\
\text { The idea that there is one supreme spirit that powers all human and other-than-human } \\
\text { entities lends reverence and sanctity to everything present in a physical environment. For } \\
\text { instance, unnecessarily cutting down trees is killing oneself as the soul that dwells in both the } \\
\text { human and the tree is the same. The same idea of a shared soul converts the built } \\
\text { environment from anthropocentric to cosmos-centric. This encourages environmental } \\
\text { sustainability. }\end{array}$ \\
\hline
\end{tabular}

A residential unit was a place of habitation as well as work. In other words, home was where a possibility of sustenance could be created through interaction with nature. In this regard, terracing was adopted that corresponded to the terrain, provided levelled ground for residences, and prevented soil erosion and nutrient loss. Terrain informed the settlement style, which is non-orthogonal, spread out, and interspersed with areas for urban agriculture [12]. Common houses were made of local building materials, including 
perishable materials. Agricultural by-products and organic materials were used in layers for the ground floor construction. Mayan landscapes were lively, resulting from the interactions between social organization and the ecology of the surrounding locale, mutually benefitting all stakeholders living in an environment.

\subsection{Urban Agriculture}

The notion that urban living can be detached from rural still exists in some contemporary urban studies. The Maya, however, present a different case. Their settlements promote organic food production and ensure food security. Urban agriculture ensured crop yield while, at the same time, it did not rely on artificial fertilizer or pesticides. Human and animal waste was recycled and used as fertilizer that provided natural phosphorus to crops [48]. Taking environmental feedback into consideration, farming retained the natural features of the land without disturbing the local ecology. Given the rotation of crops, forest locations, and fallow land, the Mayan-built environment was dynamic, perfectly responding to the climate and the ecological allowances of a locale. Introduction of new plants was performed carefully, which, together with sustainable soil management, enabled native and new plants to thrive. There were primary and secondary locations for farming and living to be occupied for the purpose of acquiring additional production when needed.

Through maintaining native plants and domesticating foreign plants, the Maya were able to create an environment that offered shade and fruits. This, along with terrace construction and raised fields in certain built environments, resulted in a unique landscape pattern that is distinct from the deforestation and mono-cropping of the present time [104] an increase in soil fertility is noted in these aggraded Mayan landscapes. It appears that the Mayans' impact on ecological systems helped many plant species to thrive, for instance cacao and pine groves in the northern Yucatan and Peten, respectively. Cultivation method, crop selection, and rotation did not deplete the soil of naturally occurring nutrients.

The Maya possessed highly developed ecological knowledge acquired over generations [41]. The knowledge of plant biology and soil type converted the less fertile lands into productive ones. For instance, maize was successfully grown in large quantities on land that was mostly unfavorable. This ability of the Maya formed anthropogenic landscapes, which were full of life and extended benefits, even on infertile terrain [50]. Crop cultivation was climate determined and frequently conducted near homes to facilitate harvesting and conservation, which proved successful as it imitated the way the ecosystems of the area functioned [101]. In the event of dry season, there was a shift from extensive to intensive cropping, swidden agriculture was reduced, and appropriate crops were selected to grow well in dry weather. In addition, mulching was introduced to retain moisture in the ground [43]. Moreover, protecting the forest cover controls the climate and provides other ecological benefits. Ancient forests that were cared for by the Maya survive even today, presenting another instance of the Mayan ecological legacy [43].

\subsection{Water Conservation}

Water conservation was essential during the Classic Maya Period. Water supply under gravity, construction of a variety of artificial channels and reservoirs, and capitalizing on naturally occurring water bodies made the Mayan-built environment contextual, climatically responsive, and resilient, especially during the dry months. The way the natural wetland biosphere functioned was mimicked to keep water clean in various reservoirs [41]. The blue-green infrastructure constructed by the Maya was sustainable. This included terrace walls that retained moisture and nutrients, artificial reservoirs, and modified natural reservoirs. The green infrastructure consisted of systematized green areas providing various ecosystem services such as gardening, leisure, flood protection, improving air quality, and reducing UHI effect.

Given the scarcity of water during the dry season, familiarity with the terrain, drainage routes, and moisture absorption of the soil, the Maya utilized natural and human-made water reservoirs. Potable water was obtained through imitating the wetland biosphere 
functions. Terrace walls retained moisture and prevented soil erosion. These also provided space for human residences that were made from perishable and recyclable materials. Through multiplicity of green cover and water reservoirs, the Maya were able to build resilience into their built environment and prevent flood risks.

\subsection{Summary of Lessons for Addressing Contemporary Urban Sustainability Challenges}

A summary of how the Mayans' ecological awareness can help mitigate the contemporary urban sustainability challenges is given in Table 4 by comparing the challenges [Column A] with lessons drawn from the Classic Mayan Period [Column B]. Briefly, emissions of GHG can be reduced if both production and consumption are localized. Emissions will further come down if production is linked with the carrying capacity of a region not overshooting the ecosystems. Connected to this is the provision of urban agriculture that will not only control UHI effect but, along with forestation, also function as a sponge to absorb torrential rains. If they are based on human labor, urban agriculture and its associated professions can provide self-sufficiency leading to availability of work and controlling the outflow of the local population looking for work. It will also cut down imports. Recycling is yet another lesson that can be learned from the Classic Mayan Period. When coupled with downscaled production and green human labor, recycling can significantly control all kinds of pollution. The end result of all of these actions is a built environment where the ecosystems are respected, where the natural setting of a locale is not altered and retain its identity, and where humans are part of their surroundings, all giving rise to a built environment that is ecologically embedded.

Table 4. Summary of lessons the Mayan-built environments can offer toward addressing current urban sustainability challenges.

\begin{tabular}{|c|c|}
\hline Urban Sustainability Challenges & Solutions from the Ecological Embeddedness of the Mayan-Built Environment \\
\hline High rate of GHG emissions and air pollution $[3,5]$ & $\begin{array}{l}\text { There is no mass scale production and consumption. This situation lowers } \\
\text { emissions and maintains a normal climate [21]. }\end{array}$ \\
\hline $\begin{array}{c}\text { Extensive transportation infrastructure adversely affects the } \\
\text { natural landscape [16] }\end{array}$ & $\begin{array}{l}\text { Both production and consumption are localized, and land-use is mixed, } \\
\text { significantly reducing mobility and other infrastructure needs }[64,105]\end{array}$ \\
\hline $\begin{array}{l}\text { Mass production and unsustainable consumption } \\
\text { lifestyle [27] }\end{array}$ & $\begin{array}{l}\text { Role played by 'intense market' is limited. There is a communal and symbiotic } \\
\text { way of life }[41,43] \text {. Conservation is a religious duty [48]. }\end{array}$ \\
\hline High levels of air, land, and water pollution $[4,30]$ & $\begin{array}{l}\text { Settlement density is appropriate and coupled with downscaled production, the } \\
\text { environment is clean }[35,58,61] \text {. All waste is recyclable and biodegradable [106]. }\end{array}$ \\
\hline Alienation from one's land and food insecurity [107] & $\begin{array}{l}\text { People are embedded in their locale. Food security is a high priority achieved } \\
\text { through urban agriculture and gardening }[44,50] \text {. }\end{array}$ \\
\hline $\begin{array}{l}\text { Cities overly dependent on unsustainable energy and } \\
\text { technologies }[2,14,108]\end{array}$ & $\begin{array}{l}\text { Green human labor defines the work style. Society respects the ecological } \\
\text { allowances and ensured a fair outcome [109]. Buildings utilize natural lighting } \\
\text { and ventilation [66]. }\end{array}$ \\
\hline $\begin{array}{l}\text { Urban areas depend on imports that are susceptible to } \\
\text { disruptions and have enormous carbon footprints [4] }\end{array}$ & $\begin{array}{l}\text { Production areas lie within the built environment, imports are limited to mainly } \\
\text { non-essential items, and risks are spread out }[40,93,110] \text {. This makes availability of } \\
\text { life essentials predictable without any significant carbon footprint. }\end{array}$ \\
\hline Urban flooding $[31,32]$ & $\begin{array}{l}\text { Maya settlements act as sponge cities. Blue-green infrastructure absorbs run-off } \\
\text { and significantly reduces flooding }[36,40,77,89,102] \text {. }\end{array}$ \\
\hline Urban heat islands and sprawl $[15,25,26,111]$ & $\begin{array}{c}\text { Towns are medium to low density, mixed uses. Landscaping, water reservoirs, and } \\
\text { urban agriculture are widespread, which capture carbon and absorb } \\
\text { heat }[12,105,112] .\end{array}$ \\
\hline Inequality and unemployment $[13,29]$ & $\begin{array}{c}\text { There is fair guarantee of production [113]. Due to intensive labor requirement, } \\
\text { individuals are not without work [107]. }\end{array}$ \\
\hline
\end{tabular}

The principle of mixed land uses in the Mayan-built environment can help contemporary cities reduce urban sprawl and rising temperatures by minimizing the need to travel long distances. Building configuration that allows the use of natural lighting and ventilation is another lesson for creating more sustainable settlements. As in the Mayan-built environment, there is the need to promote indigenous building materials because they are low cost, reusable and recyclable, thus lowering energy use and increasing housing 
affordability. Participatory maintenance of the built environment is yet another Mayan feature than can bring humans and their environment together through interactions on multiple levels. This can strike a balance between top-down and bottom-up decisions and ensure timely reception of environmental feedback.

\section{Concluding Remarks}

The Mayan civilization is one of those eras of human history known for its environmental legacy and ecological wisdom. In the face of growing environmental and societal challenges, taking inspiration from Mayan culture may help us, in part at least, to shed light on possible solutions regarding contemporary urban sustainability issues. This civilization inspires us to achieve environmental sustainability through settlement patterns that promote mixed land use, walkability, native and recyclable construction materials, natural light and ventilation in buildings, and complete waste recycling. Urban agriculture and gardening capture carbon improve air quality, serve as windbreaks, reduce soil erosion, and ensure food security via organic food production. Water conservation through canals and reservoirs provides sufficient water for household and agricultural purposes, even during droughts. Water reservoirs are multifunctional, offering ecological, spiritual, and socioeconomic benefits, including food production, recreation, and curbing UHI effect and floods.

Mayans conducted their socioeconomic activities within the ecological allowances of a given locality and listened to and addressed the environmental feedback. All components of the ecosystem, such as land, vegetation, water, air, and animals, were revered and protected. Human activities harmoniously co-existed with the ecosystem and were linked to the culture and history of the society. As a result, the Mayans lived with and adapted to the favorable and unfavorable environmental changes within their context. These inspirations of Maya culture and their relevance are a significant and ethical frame worthy of adoption today, especially in the face of increasing urban sustainability challenges.

This study has some important implications for towns and cities in developing countries, which are the future of global urbanization because of their rapid population growth and expansion. The present study contributed to the recent search for sustainable urban solutions to the existing environmental problems using the values of Mayans' ecological wisdom accumulated through long historical experience. The study applied a holistic approach to improving land-use planning of contemporary cities based on the principles of the Mayans' settlement patterns, building configuration and construction, urban agriculture, home gardening, and water conservation. In addition, the heritage left by the ancient Maya civilization provides remarkable inspiration for this and future generations.

This study raises a fundamental question for the scholarship on contemporary cities. What are the challenges to theoretically and practically interpret the ecological wisdom of ancient civilizations when planning and managing overpopulated cities with the enormously increased complexity of interactions, high resource consumption, climate change, and pollution? From a strategic urban policy and planning perspective, future studies are needed to further operationalize the idea of ecological embeddedness. The ecological embeddedness of this ancient civilization proffers invaluable inspirations for addressing the environmental challenges of contemporary cities towards developing more sustainable built environments.

Author Contributions: Conceptualization: N.A.; methodology: I.R.A.; investigation: N.A., I.R.A., A.A.S., and W.A.-M.; data curation: N.A., I.R.A., A.A.S., and W.A.-M.; writing-original draft preparation: N.A., A.A.S., and W.A.-M.; writing—review and editing: I.R.A.; supervision: I.R.A.; project administration: N.A.; funding acquisition: I.R.A., A.A.S., and W.A.-M. All authors have read and agreed to the published version of the manuscript.

Funding: This research received no external funding. 
Acknowledgments: Naji Akbar thanks Noel G. Keough, David P. Monteyne, Elizabeth H. Paris, Mohammed Alhefnawi, and Engr. Rehan Jamil for commenting on the draft manuscript, as well as Engr. Yazeed Alshiddi for assistance with selected images.

Conflicts of Interest: The authors declare no conflict of interest in conducting this study.

\section{References}

1. Harvey, D. The urban process under capitalism: A framework for analysis. In Urbanization and Urban Planning in Capitalist Society; Routledge: New York, NY, USA, 2020; pp. 91-121.

2. Moran, D.; Kanemoto, K.; Jiborn, M.; Wood, R.; Többen, J.; Seto, K.C. Carbon footprints of 13000 cities. Environ. Res. Lett. 2018, 13, 064041. [CrossRef]

3. UN-Habitat. Global Report on Human Settlements 2011: Cities and Climate Change; Earthscan: London, UK, 2011.

4. Newman, P. The environmental impact of cities. Environ. Urbaniz. 2006, 18, 275-295. [CrossRef]

5. United Nations. Cities and Pollution. Cities and Local Action; United Nations: New York, NY, USA, 2021. Available online: https:/ / www.un.org/en/climatechange/climate-solutions/cities-pollution (accessed on 16 October 2021).

6. Gail, W.; Cooper, W.H. Ecological embeddedness. Acad. Manag. J. 2000, 43, 1265-1282.

7. Guttmann-Bond, E. Sustainability out of the past: How archaeology can save the planet. World Archaeol. 2010, 42, 355-366. [CrossRef]

8. Hornborg, A. Ecological embeddedness and personhood. Anthropol. Today 1998, 14, 3. [CrossRef]

9. Mu'azu, N.D.; Abubakar, I.R.; Blaisi, N.I. Public acceptability of treated wastewater reuse in Saudi Arabia: Implications for water management policy. Sci. Total Environ. 2020, 721, 137659. [CrossRef] [PubMed]

10. Wang, X.; Palazzo, D.; Carper, M. Ecological wisdom as an emerging field of scholarly inquiry in urban planning and design. Landsc. Urban Plan. 2016, 155, 100-107. [CrossRef]

11. Abubakar, I.R.; Bununu, Y.A. Low carbon city: Strategies and case studies. In Sustainable Cities and Communities. Encyclopedia of Sustainability in Higher Education; Springer: Cham, Switzerland, 2020; pp. 366-376.

12. Barthel, S.; Isendahl, C. Urban gardens, agriculture, and water management: Sources of resilience for long-Term food security in cities. Ecol. Econ. 2013, 86, 224-234. [CrossRef]

13. Campbell, S. Green Cities, Growing Cities, Just Cities? Urban Planning and the Contradictions of Sustainable Development. J. Am. Plan. Assoc. 2007, 62, 296-312.

14. Watson, V. The planned city sweeps the poor away: Urban planning and 21st century urbanisation. Prog. Plan. 2009, 72, 151-193.

15. Smith, M.E. The archaeological study of neighborhoods and districts in ancient cities. J. Anthropol. Archaeol. 2010, 29, 137-154. [CrossRef]

16. Akbar, N.; Abubakar, I.R.; Bouregh, A.S. Fostering Urban Sustainability through the Ecological Wisdom of Traditional Settlements. Sustainability 2020, 12, 10033. [CrossRef]

17. Ardelt, M. Wisdom as expert knowledge system: A critical review of a contemporary operationalization of an ancient concept. Hum. Dev. 2004, 47, 257-285. [CrossRef]

18. Yoffee, N. Making ancient cities plausible. Rev. Anthropol. 2009, 38, 264-289. [CrossRef]

19. Pérez Rodríguez, V.; Anderson, K.C.; Neff, M.K. The Cerro Jazmín Archaeological Project: Investigating prehispanic urbanism and its environmental impact in the Mixteca Alta, Oaxaca, Mexico. J. Field Archaeol. 2011, 36, 83-99. [CrossRef]

20. Roberts, P.; Hunt, C.; Arroyo-Kalin, M.; Evans, D.; Boivin, N. The deep human prehistory of global tropical forests and its relevance for modern conservation. Nat. Plants 2017, 3, 1-9. [CrossRef] [PubMed]

21. Akbar, N. Surveying the Ecologically Embedded Built Environments of the Preindustrial Era with a Focus on the Classic Maya. Unpublished Master's Thesis, University of Calgary, Calgary, Canada, 2021.

22. Yang, B.; Young, R.F. (Eds.) Ecological Wisdom: Theory and Practice; Springer: Berlin/Heildberg, Germany, 2019.

23. Kakoty, S. Ecology, sustainability and traditional wisdom. J. Clean. Prod. 2018, 172, 3215-3224. [CrossRef]

24. Turner, N.J.; Ignace, M.B.; Ignace, R. Traditional ecological knowledge and wisdom of aboriginal peoples in British Columbia. Ecol. Appl. 2000, 10, 1275-1287. [CrossRef]

25. Buo, I.; Sagris, V.; Burdun, I.; Uuemaa, E. Estimating the expansion of urban areas and urban heat islands (UHI) in Ghana: A case study. Nat. Hazards 2021, 105, 1299-1321. [CrossRef]

26. Aina, Y.A.; Parvez, I.M.; Balogun, A.L.; Adam, E. Urban Heat Island Effects and Mitigation Strategies in Saudi Arabian Cities. In Urban Heat Island (UHI) Mitigation; Springer: Singapore, 2021; pp. 235-248.

27. Almulhim, A.I.; Abubakar, I.R. Understanding Public Environmental Awareness and Attitudes toward Circular Economy Transition in Saudi Arabia. Sustainability 2021, 13, 10157. [CrossRef]

28. Ferreira, C.S.; Walsh, R.P.; Ferreira, A.J. Degradation in urban areas. Curr. Opin. Environ. Sci. Health 2018, 5, 19-25. [CrossRef]

29. Abubakar, I.R. Strategies for coping with inadequate domestic water supply in Abuja, Nigeria. Water Internat. 2018, 43, 570-590. [CrossRef]

30. Joshi, R.; Ahmed, S. Status and challenges of municipal solid waste management in India: A review. Cogent Environ. Sci. 2016, 2, 1139434. [CrossRef]

31. Bulkeley, H. Urban sustainability: Learning from best practice? Environ. Plan. A 2006, 38, 1029-1044. [CrossRef] 
32. Dano, U.L. An AHP-Based assessment of flood triggering factors to enhance resiliency in Dammam, Saudi Arabia. Geo J. 2021, 1-16. [CrossRef]

33. Ashmore, W. Site-Planning principles and concepts of directionality among the ancient Maya. Lat. Am. Antiq. 2017, 2, 199-226. [CrossRef]

34. Munson, J.; Pinzón, F. Building an Early Maya Community: Archaeological Investigations at CAOBAL, Guatemala. Anc. Mesoam. 2017, 28, 265-278. [CrossRef]

35. Murtha, T. Rethinking Urban Density: Archaeology, Low Density Urbanism and Sustainability Lowland Maya Landscape Regionalism. In Proceedings of the Architecture, Archaeology and Contemporary City Planning, Valencia, Spain, 18-20 May 2015; pp. 92-100.

36. Davis-Salazar, K.L. Late Classic Maya drainage and flood control at Copan, Honduras. Anc. Mesoam. 2006, 17, 125-138. [CrossRef]

37. Dine, H.; Ardren, T.; Bascopé, G.; Báez, C.G. Famine Foods and Food Security in the Northern Maya Lowlands: Modern Lessons for Ancient Reconstructions. Anc. Mesoam. 2019, 30, 517-534. [CrossRef]

38. Turner, B.L.; Sabloff, J.A. Classic Period collapse of the Central Maya Lowlands: Insights about human-Environment relationships for sustainability. Proc. Natl. Acad. Sci. USA 2012, 109, 13908-13914. [CrossRef]

39. Hansen, R.D.; Bozarth, S.; Jacob, J.; Wahl, D.; Schreiner, T. Climatic and Environmental Variability in the Rise of Maya Civilization: A preliminary perspective from northern Peten. Anc. Mesoam. 2002, 13, 273-295. [CrossRef]

40. Lucero, L.J.; Fedick, S.L.; Dunning, N.P.; Lentz, D.L.; Scarborough, V.L. Water and landscape: Ancient Maya settlement decisions. Archeol. Pap. Am. Anthropol. Assoc. 2014, 24, 30-42. [CrossRef]

41. Lucero, L.J.; Gunn, J.D.; Scarborough, V.L. Climate Change and Classic Maya Water Management. Water 2011, 3, 479-494. [CrossRef]

42. Meanwell, J.L.; Paris, E.H.; Cruz Alvarado, W.; Peraza Lope, C. Metallurgical ceramics from Mayapán, Yucatán, Mexico. J. Archaeol. Sci. 2013, 40, 4306-4318. [CrossRef]

43. Beach, T.; Luzzadder-Beach, S.; Cook, D.; Dunning, N.; Kennett, D.J.; Krause, S.; Terry, R.; Trein, D.; Valdez, F. Ancient Maya impacts on the Earth's surface: An Early Anthropocene Analog? Quat. Sci. Rev. 2015, 124, 1-30. [CrossRef]

44. Ford, A. Valuing the Maya Forest as a Garden. In Tropical Forest Conservation: Long-Term Processes of Human Evolution, Cultural Adaptations and Consumption Patterns; Lewis, R.C., Mata, J.P., Connaughton, C., Eds.; United Nations Educational, Scientific and Cultural Organization: Paris, France, 2016; pp. 207-226.

45. Hammond, N. Maya: Revelation and re-Evaluation. Antiquity 2015, 89, 1503-1510. [CrossRef]

46. Ashmore, W. City and Town Planning of the Maya. In Encyclopaedia of the History of Science, Technology, and Medicine in Non-Western Cultures; Selin, H., Ed.; Springer: Dordrecht, Germany, 2014; pp. 1-9.

47. Zaro, G.; Lohse, J.C. Agricultural Rhythms and Rituals: Ancient Maya Solar Observation in Hinterland Blue Creek, Northwestern Belize. Lat. Am. Antiq. 2005, 16, 81-98. [CrossRef]

48. Lucero, L.J.; Gonzalez Cruz, J. Reconceptualizing Urbanism: Insights from Maya Cosmology. Front. Sustain. Cities 2020, 2, 1-15. [CrossRef]

49. Garrison, T.G.; Houston, S.D.; Scherer, A.K.; del Cid, D.; Garrido López, J.L.; Czapiewska-Halliday, E.; Román, E. A royal Maya country house: Archaeology at Bejucal, Guatemala. J. Field Archaeol. 2016, 41, 532-549. [CrossRef]

50. Fedick, S.L. Land Evaluation and Ancient Maya Land Use. In The Upper Belize River Area, Belize, Central America; Cambridge University Press: Cambridge, UK, 2018.

51. McCane, C.A.; Macrae, S.A.; Iannone, G.A. Consideration of the Spatial Arrangement of Settlement Groups and Terraces in Contreras, Minanha, Belize. Res. Rep. Belizean Archaeol. 2010, 7, 141-151.

52. Chase, D.Z.; Chase, A.F. Caracol, Belize, and Changing Perceptions of Ancient Maya Society. J. Archaeol. Res. 2017, 25, 185-249. [CrossRef]

53. Paris, E.H.; Taladoire, E.; Whiting, T.A.L. Return to Moxviquil: Form and Function in a Small Maya City. Anc. Mesoam. 2015, 26, 81-112. [CrossRef]

54. Peuramaki-Brown, M. The Integration and Disintegration of Ancient Maya Urban Centres: Charting Households and Community at Buenavista del Cayo, Belize. Unpublished Ph.D. Thesis, University of Calgary, Calgary, AB, Canada, 2012.

55. Brady, E.J.; Ashmore, W. Mountains, Caves, Water: Ideational Landscapes of the Ancient Maya. In Archaeologies of Landscape: Contemporary Perspectives; Blackwell: Hoboken, NJ, USA, 1999; pp. 124-145.

56. Eppich, K. Book Review: Maya Cities and Villages. Lat. Am. Antiq. 2016, 27, 132-134.

57. Restall, M. Maya Ethnogenesis. J. Lat. Am. Anthropol. 2008, 9, 64-89. [CrossRef]

58. Isendahl, C.; Smith, M.E. Sustainable agrarian urbanism: The low-Density cities of the Mayas and Aztecs. Cities 2013, 31, 132-143. [CrossRef]

59. Tsukamoto, K.; Camacho, J.L.; Valenzuela, L.E.C.; Kotegawa, H.; Esparza Olguín, O.Q. Political Interactions among Social Actors: Spatial Organization at the Classic Maya Polity of El Palmar, Campeche, Mexicó. Lat. Am. Antiq. 2015, 26, 200-220. [CrossRef]

60. Stark, B.L.; Ossa, A. Ancient Settlement, Urban Gardening, and Environment in the Gulf Lowlands of Mexico; Cambridge University Press: Cambridge, UK, 2019.

61. Smith, M.E. Classic Maya Settlement Clusters as Urban Neighborhoods: A Comparative Perspective on Low-Density Urbanism. J. De La Société Des Américanistes 2011, 97, 51-73. [CrossRef] 
62. Masson, M.A.; Freidel, D.A. An argument for Classic era Maya market exchange. J. Anthropol. Archaeol. 2012, 31, 455-484. [CrossRef]

63. Ford, A.; Nigh, R. The Milpa Cycle and the making of the Maya forest garden. Res. Rep. Belizean Archaeol. 2010, 7, 183-190.

64. Farahani, A.; Chiou, K.L.; Harkey, A.; Hastorf, C.A.; Lentz, D.L.; Sheets, P. Identifying 'plantscapes' at the Classic Maya village of Joya de Cerén, El Salvador. Antiquity 2017, 91, 980-997. [CrossRef]

65. Pugh, T.W.; Rice, P.M. Early urban planning, Spatial strategies, and the Maya gridded city of nixtun-Ch'ich', Petén, Guatemala. Curr. Anthropol. 2017, 58, 576-603. [CrossRef]

66. Richards-Rissetto, H. An iterative 3D GIS analysis of the role of visibility in ancient Maya landscapes: A case study from Copan, Honduras. Digit. Scholarsh. Humanit. 2017, 32, 195-212. [CrossRef]

67. Landau, K. Spatial logic and Maya city planning: The case for cosmology. Camb. Archaeol. J. 2015, 25, 275-292. [CrossRef]

68. Hutson, S.R.; Stanton, T.W.; Magnoni, A.; Terry, R.; Craner, J. Beyond the buildings: Formation processes of ancient Maya houselots and methods for the study of non-Architectural space. J. Anthropol. Archaeol. 2007, 26, 442-473. [CrossRef]

69. Ashmore, W.; Sabloff, J.A. Spatial Orders in Maya Civic Plans. Latin American Antiquity. Soc. Am. Archaeol. 2002, 13, $201-215$.

70. Shaw, M.J. 17-Maya Sacbeob: Form and function. Anc. Mesoam. 2001, 12, 261-272. [CrossRef]

71. Stanton, T.W.; Freidel, D.A. Placing the centre, centring the place: The influence of formative Sacbeob in classic site design at Yaxuná, Yucatán. Camb. Archaeol. J. 2005, 15, 225-249. [CrossRef]

72. Grauer, K.C. Active environments: Relational ontologies of landscape at the ancient Maya city of Aventura, Belize. J. Soc. Archaeol. 2020, 20, 74-94. [CrossRef]

73. Wernecke, D.C. A Stone Canvas: Interpreting Maya Building Materials and Construction. Unpublished Ph.D. Thesis, The University of Texas, Austin, TX, USA, 2005.

74. Becker, M. Ancient Maya houses and their identification: An evaluation of architectural groups at Tikal and inferences regarding their functions. Rev. Española De Antropol. Am. 1982, 12, 111-130.

75. Graham, E. Stone Cities, Green Cities. Archeol. Pap. Am. Anthropol. Assoc. 2008, 9, 185-194. [CrossRef]

76. Abrams, E.M. Economic Specialization and Construction Personnel in Classic Period Copan, Honduras; Cambridge University Press: Cambridge, UK, 2019; pp. 485-499.

77. French, K.D.; Duffy, C.J.; Bhatt, G. The urban hydrology and hydraulic engineering at the classic Maya site of Palenque. Water Hist. 2013, 5, 43-69. [CrossRef]

78. Stuart, D.S. The Hills Are Alive: Sacred Mountains in the Maya Cosmos. Symbols 1997, 13, 13-17.

79. Sprajc, I. Astronomical and Cosmological Aspects of Maya Architecture and Urbanism. Cosmol. Across Cult. 2009, 409, 303-314.

80. Barr, V.A. Mayan Engineering Legacy: Coba. Mech. Eng. 1990, 112, 66-71.

81. Hammond, N.; Gerhardt, J.C. Early Maya architectural innovation at Cuello, Belize. World Archaeol. 1990, 21, 461-481. [CrossRef]

82. Robin, C. Outside of houses. J. Soc. Archaeol. 2002, 2, 245-268. [CrossRef]

83. Magnoni, A.; Hutson, S.R.; Dahlin, B.H. Living in the city: Settlement patterns and the urban experience at classic period Chunchucmil, Yucatan, Mexico. Anc. Mesoam. 2012, 23, 313-343. [CrossRef]

84. Ford, A. Maya Forest Garden. In Encyclopedia of Global Archaeology; Springer: Cham, Switzerland, 2020; pp. 1-11.

85. Halperin, C.T.; Foias, A. Household Garbage: Classic period (ca. 300-900 CE) Maya Practices of Discard. J. Field Archaeol. 2016, 8, 45. [CrossRef]

86. Doyle, J.A. Early Maya geometric planning conventions at El Palmar, Guatemala. J. Archaeol. Sci. 2013, 40, 793-798. [CrossRef]

87. Hughbanks, P.J. Settlement and Land Use at Guijarral, Northwest Belize. Cult. Agric. 2008, 20, 107-120. [CrossRef]

88. Fisher, C. The role of infield agriculture in Maya cities. J. Anthropol. Archaeol. 2014, 36, 196-210. [CrossRef]

89. Scarborough, V.L.; Gallopin, G.G. A Water Storage Adaptation in the Maya Lowlands. Science 1991, 251, 658-662. [CrossRef] [PubMed]

90. Lucero, L.J. A Cosmology of Conservation in the Ancient Maya World. J. Anthropol. Res. 2018, July, 327-359. [CrossRef]

91. Dahlin, B.H.; Bastamow, M.; Beach, T.; Hruby, Z.X.; Hutson, S.R.; Mazeau, D. Phantom Lithics at Chunchucmil, Yucatán, Mexico. Technol. Maya Civiliz. Politic. Econ. Beyond Lithic Stud. 2009, 156-178.

92. Bates, A. The Gift of the Maya. The Great Change. 2015. Available online: https://peaksurfer.blogspot.com/2015/07/the-gift-ofmaya.html (accessed on 2 October 2021).

93. Dunning, N.P.; Beach, T. Farms and Forests: Spatial and Temporal Perspectives on Ancient Maya Landscapes. In Landscapes and Societies; Martini, I.P., Chesworth, W., Eds.; Springer: Dordrecht/Heidelberg, Germany; London, UK; New York, NY, USA, 2010; pp. 369-390.

94. Lohse, J.C.; Findlay, N.P. A Classic Maya House-Lot Drainage System in Northwestern Belize. Lat. Am. Antiq. 2000, 11, 175-185. [CrossRef]

95. Castro, A.; Lascurain-Rangel, M.; Gómez-Díaz, J.A.; Sosa, V. Mayan Homegardens in Decline: The Case of the Pitahaya (Hylocereus Undatus), a Vine Cactus with Edible Fruit. Trop. Conserv. Sci. 2018, 11, 1-10. [CrossRef]

96. Dedrick, M.; Webb, E.A.; McAnany, P.A.; Kanxoc Kumul, J.M.; Jones, J.G.; Batún Alpuche, A.I.; Pope, C.; Russell, M. Influential landscapes: Temporal trends in the agricultural use of Rejolladas at Tahcabo, Yucatán, Mexico. J. Anthropol. Archaeol. 2020, 59, 101175. [CrossRef]

97. Martínez-Ballesté, A.; Martorell, C.; Caballero, J. Cultural or ecological sustainability? The effect of cultural change on Sabal palm management among the lowland Maya of Mexico. Ecol. Soc. 2006, 11, 27. [CrossRef] 
98. Poot-Pool, W.S.; van der Wal, H.; Flores-Guido, S.; Pat-Fernández, J.M.; Esparza-Olguín, L. Economic Stratification Differentiates Home Gardens in the Maya Village of Pomuch, Mexico. Econ. Bot. 2012, 66, 264-275. [CrossRef]

99. Rojas, M.O.; Collins, S.; Cal, V.; Caal, F.; Knight, K.; Arnason, J.; Poveda, L.; Sanches-Vindas, P.; Pesek, T. Sustaining Rainforest Plants, People and Global Health: A Model for Learning from Traditions in Holistic Health Promotion and Community Based Conservation as Implemented by Q'eqchi' Maya Healers, Maya Mountains, Belize. Sustainability 2010, 2, 3383-3398. [CrossRef]

100. Brewer, J.L.; Carr, C.; Dunning, N.P.; Walker, D.S.; Anaya Hernández, A.; Peuramaki-Brown, M.; Reese-Taylor, K. Employing airborne lidar and archaeological testing to determine the role of small depressions in water management at the ancient Maya site of Yaxnohcah, Campeche, Mexico. J. Archaeol. Sci. 2017, 13, 291-302. [CrossRef]

101. Scarborough, V.L. Ecology and Ritual: Water Management and the Maya. Lat. Am. Antiq. 1998, 9, 135-159. [CrossRef]

102. Scarborough, V.L.; Dunning, N.P.; Tankersley, K.B.; Carr, C.; Weaver, E.; Grazioso, L.; Lane, B.; Jones, J.G.; Buttles, P.; Valdez, F.; et al. Water and sustainable land use at the ancient tropical city of Tikal, Guatemala. Proc. Natl. Acad. Sci. USA 2012, 109, 12408-12413. [CrossRef] [PubMed]

103. Healy, P.F. An Ancient Maya Dam in the Cayo District, Belize. J. Field Archaeol. 1983, 10, 147.

104. Wilk, R.R. Little house in the jungle: The causes of variation in house size among modern Kekchi Maya. J. Anthropol. Archaeol. 1983, 2, 99-116. [CrossRef]

105. Marken, D.; Murtha, T. Maya Cities, People and Place: Comparative Perspectives from El Peru and Tikal. Paper Presented at the 14th Belize Archeology Symposium, San Ignacio, Belize, 1 July 2016.

106. Smyth, M.P.; Dore, C.D.; Dunning, N.P. Interpreting prehistoric settlement patterns: Lessons from the Maya center of Sayil, Yucatan. J. Field Archaeol. 1995, 22, 321-347.

107. Williams, D.R.; Stewart, S.I. Sense of Place: An Elusive Concept That Is Finding a Home in Ecosystem Management. J. For. 1998, $5,18-23$.

108. Alshuwaikhat, H.M.; Abubakar, I. Towards a sustainable urban environmental management approach (SUEMA): Incorporating environmental management with strategic environmental assessment (SEA). J. Environ. Plan. Manag. 2007, 50, 257-270. [CrossRef]

109. Scarborough, V.L.; Burnside, W.R. Complexity and Sustainability: Perspectives from the Ancient Maya and the Modern Balinese. Am. Antiq. 2010, 75, 327-363. [CrossRef]

110. Chase, D.Z.; Chase, A.F. Path dependency in the rise and denouement of a classic Maya City: The case of Caracol, Belize. Archeol. Pap. Am. Anthropol. Assoc. 2014, 24, 142-154. [CrossRef]

111. Rees, W.; Wackernagel, M. Urban Ecological Footprint: Why Cities Cannot Be Sustainable and Why They Are a Key to Sustainability. Environ. Impact Assess. Rev. 1996, 16, 223-248. [CrossRef]

112. Robinson, M.E.; McKillop, H.I. Ancient Maya wood selection and forest exploitation: A view from the Paynes Creek salt works, Belize. J. Archaeol. Sci. 2013, 40, 3584-3595. [CrossRef]

113. Patten, D.T. The role of ecological wisdom in managing for sustainable interdependent urban and natural ecosystems. Landsc. Urban Plan. 2016, 155, 3-10. [CrossRef] 